\title{
Michael Additions of Thiocompounds to $\alpha, \beta$-Unsaturated Carbonyl Compounds in Aqueous Media: Stereoselectivity with Unambiguous Characterization by NMR
}

\author{
Queli Aparecida Rodrigues de Almeida, ${ }^{a}$ Maria Luiza de Oliveira Pereira, ${ }^{a}$ Ricardo Bezerra Coelho, ${ }^{a}$ \\ Erika Martins de Carvalho, ${ }^{b}$ Carlos Roland Kaiser, ${ }^{a}$ Joel Jones Junior ${ }^{*, a}$ and Flavia Martins da Silva ${ }^{*, a}$
}

\author{
${ }^{a}$ Departamento de Química Orgânica, Instituto de Química, Universidade Federal do Rio de Janeiro, \\ CP 68.584, 21941-972 Rio de Janeiro-RJ, Brazil \\ ${ }^{b}$ Instituto de Tecnologia em Fármacos, Far-Manguinhos, Rua Sizenando Nabuco no.100, Manguinhos, \\ 21041-250 Rio de Janeiro-RJ, Brazil
}

\begin{abstract}
As reações de crotonaldeído (8) com tiofenol (2) e benzalacetona (10) com 1,2-etanoditiol (11) levam aos produtos de adição de Michael. As reações de tiofenol (2) com $(R)$-carvona (13) e $(S)$-perilaldeído $(\mathbf{1 5})$ levam aos produtos $(2 S, 3 R, 5 S)$-5-isopropenil-2-metil-3-feniltio-cicloexanona (14) e (1R,2R,4S)-4-isopropenil-2-feniltio-cicloexano carbaldeído (16), respectivamente. Também é apresentada a elucidação inequívoca da estereoquímica de 14 e 16 por RMN.
\end{abstract}

\begin{abstract}
The reactions of crotonaldehyde (8) with thiophenol (2) and benzalacetone (10) with ethane-1,2dithiol (11) yield Michael addition products. The reactions of thiophenol (2) with $(R)$-carvone (13) and $(S)$-perillaldehyde (15) lead to (2S,3R,5S)-5-isopropenyl-2-methyl-3-(phenylthio)cyclohexanone (14) and $(1 R, 2 R, 4 S)$-4-isopropenyl-2-(phenylthio)cyclohexanecarbaldehyde (16), respectively. An unambiguous elucidation of the stereochemistry of $\mathbf{1 4}$ and $\mathbf{1 6}$ by NMR is also presented.
\end{abstract}

Keywords: 1,4-additions, water, Green Chemistry, NMR

\section{Introduction}

At this century's threshold, the environmental conditions of our planet Earth are, and should be, one of our most serious concerns. Chemistry research may bring us great advances in the quality of life (e.g., medications, new materials, etc.), but on the other hand, it may also be responsible for several of our environmental pollution problems.

For sustainable development, ${ }^{1}$ we must think about strategies to minimize the environmental impact of these technological activities. One of these strategies is known as Green Chemistry. ${ }^{2-8}$ The objective of Green Chemistry is the development of methodologies that generate and use the lowest possible amounts of possibly toxic substances for the production of chemical compounds. ${ }^{2-8}$

Today, the study of organic reactions using water as a solvent is considered an important strategy in the area of Green Chemistry. Water is an innocuous solvent that is also abundant and inexpensive. ${ }^{9-13}$ The Michael reaction, a widely

*e-mail: soa@iq.ufrj.br used technique in organic synthesis, ${ }^{14}$ is an important tool for the preparation of various polyfunctional compounds via carbon-carbon and carbon-heteroatom bond-forming reactions. In the literature, some examples of Michael reactions in aqueous media can be found. Water-tolerant Lewis acids, ${ }^{15,20}$ Bronsted acids, ${ }^{21}$ and bases can catalyze these reactions in the presence or absence of phase transfer agents. ${ }^{22-27}$ Recently, it was reported that amphiphilic polymer-supported ammonium hydroxides are efficient heterogeneous catalysts for these reactions. ${ }^{28}$ In some cases, the Michael additions may be carried out without any type of catalysis. ${ }^{29-32}$ Moreover, it is interesting to point out that in the applications of these aqueous methodologies, many nucleophile types can be used, including organometallic regents. ${ }^{33-36}$

In our research, we have analyzed some studies of this type of reaction in water catalyzed by bases without phase transfer agents. ${ }^{37-38}$ According to King and co-workers, ${ }^{39}$ the control of $\mathrm{pH}$ is essential for the optimization of the nucleophilic reactions in aqueous media as lateral processes, such as reagent hydrolysis, compete with the desired reaction. Previously, we reported on the Michael additions of 
propane-1-thiol (1) and thiophenol (2) to cyclohex-2-enone (3) at three $\mathrm{pH}$ conditions in aqueous media ( $\mathrm{pH} 7,10,13)$. The best condition for all of the tested reactions was at $\mathrm{pH}$ 7 using a $1 \mathrm{~mol} \mathrm{~L}^{-1} \mathrm{NaHCO}_{3}$ aqueous solution. The yields were $70 \%$ and $95 \%$, respectively (Scheme 1). ${ }^{38}$

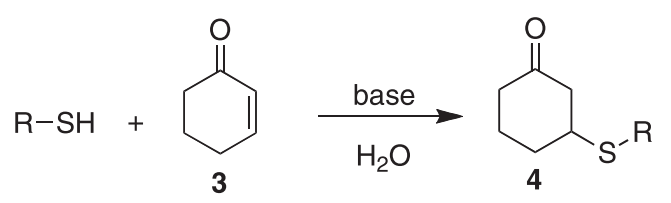

\begin{tabular}{cccc}
\hline $\mathrm{R}$ & base $(\mathrm{pH})$ & time/(h) & yield (\%) \\
\hline \multirow{3}{*}{$\mathrm{NaOH}(\mathrm{pH} \mathrm{14})$} & & 30 \\
1 & $\mathrm{Na}_{2} \mathrm{CO}_{3}(\mathrm{pH} \mathrm{10})$ & 2 & 50 \\
\hline & $\mathrm{NaHCO}_{3}(\mathrm{pH} 7)$ & & 70 \\
$\mathrm{C}_{6} \mathrm{H}_{5}$ & $\mathrm{NaOH}(\mathrm{pH} \mathrm{14})$ & & 30 \\
2 & $\mathrm{Na}_{2} \mathrm{CO}_{3}(\mathrm{pH} \mathrm{10})$ & 0.75 & 55 \\
& $\mathrm{NaHCO}_{3}(\mathrm{pH} \mathrm{7)}$ & & 95 \\
\hline
\end{tabular}

Scheme 1. Optimization of Michael addition of thiols in water.

Our research also showed that the Michael additions of thiophenol (2) to $\alpha, \beta$-unsaturated nitroolefins like 1-nitrocyclohex-1-ene (5) in aqueous media have a good diastereoselectivity; this result is cited in the literature as the first example of this kind of reaction in water that presents diastereoselectivity (Scheme 2). ${ }^{38,40}$

\section{Experimental}

Thiophenol (2), crotonaldehyde (8), benzalacetone (10), ethane-1,2-dithiol (11), $(R)$-carvone (13) and $(S)$ - perillaldehyde (15) were used as received (Aldrich). Some of the products were purified by radial chromatography in a Harrison Research Chromatotron. High resolution gas chromatography (HRGC) analyses were performed under two conditions: condition A) HP-5890-II gas chromatograph with FID, using a $30 \mathrm{~m}$ (length), 0.25 $\mathrm{mm}$ (ID) and $0.5 \mathrm{~mm}$ (phase thickness) RTX-5 silica capillary column with $\mathrm{H}_{2}$ as the gas carrier and a flow division of 1/20; condition B) Varian Star 3400cx gas chromatograph with FID, using a $30 \mathrm{~m}$ (length), $0.25 \mathrm{~mm}$ (ID) and $0.5 \mathrm{~mm}$ (phase thickness) capillary column HP1 for injection on-column, and $\mathrm{H}_{2}$ as the gas carrier. The analyses were performed in a BRUCKER-300 $\left({ }^{1} \mathrm{H}-300\right.$ $\left.\mathrm{MHz},{ }^{13} \mathrm{C}-75 \mathrm{MHz}\right)$ and in a Varian Mercury $\left({ }^{1} \mathrm{H}-400\right.$ $\mathrm{MHz},{ }^{13} \mathrm{C}-100 \mathrm{MHz}$ ) in $\mathrm{CDCl}_{3}$ and $\mathrm{C}_{6} \mathrm{D}_{6}$ as solvents, with TMS as the internal standard.

The unambiguous ${ }^{1} \mathrm{H}$ and ${ }^{13} \mathrm{C}$ NMR assignments for compounds $\mathbf{1 4}$ and 16 were obtained from COSY90, HSQC, HMBC, TOCSY and nOe. All experiments were run with a relaxation delay of $1.5 \mathrm{~s}, 65 \mathrm{~K}\left({ }^{1} \mathrm{H}\right)$ and $32 \mathrm{~K}$ $\left({ }^{13} \mathrm{C}\right)$ data points for $1 \mathrm{D}$ experiments and $2048 \times 512$ data matrixes for COSY90, TOCSY (mixing time of $25 \mathrm{~ms}$ ), nOe (mixing time of $300 \mathrm{~ms}$ ) HSQC and HMBC. Gradient selections were used in all 2D techniques. Zero filling and/or linear predictions were used in all 2D experiments. Pulse programs and data processing were performed using XWINMR 3.5 software from BRUKER.

The FT-IR spectra were recorded on a Nicolet MagnaIR-FT ( $\mathrm{NaCl}$ film).

\section{3-(Phenylthio)butyraldehyde (9)}

To $10 \mathrm{~mL}$ of a $0.5 \mathrm{~mol} \mathrm{~L}^{-1}$ aqueous $\mathrm{NaHCO}_{3}$ solution, $5 \mathrm{mmol}$ of thiophenol (2) were added. Soon after, $0.4 \mathrm{~mL}$ of a $45 \%$ aqueous crotonaldehyde $(\mathbf{8})$ solution $(2.5 \mathrm{mmol})$

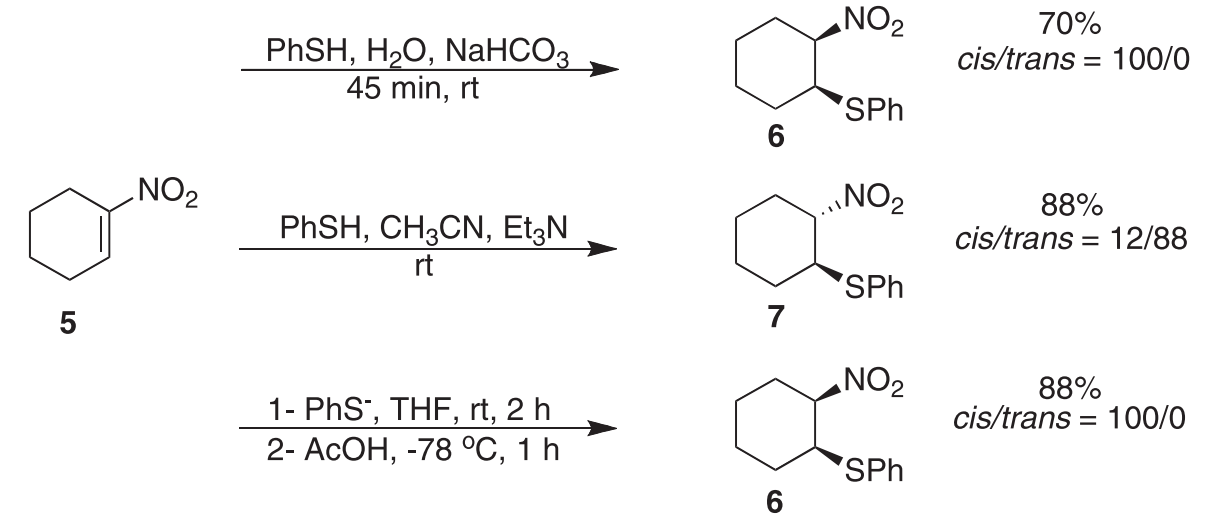

Scheme 2. Comparison of the first example of diastereoselectivity of Michael addition in water with classical methods. 
were also added. The reaction mixture was then stirred vigorously for $40 \mathrm{~min}$ at room temperature. Then, the reaction mixture was neutralized with concentrated hydrochloric acid and extracted with chloroform. The organic extract was dried (using anhydrous $\mathrm{Na}_{2} \mathrm{SO}_{4}$ ), and the solvent was evaporated under reduced pressure. The product was purified by radial chromatography using chloroform as a solvent. $0.34 \mathrm{~g}$ of product was obtained. The following spectroscopic data were obtained: IR (KBr) $v_{\max } / \mathrm{cm}^{-1} 2825,2727,1724,748,693 ;{ }^{1} \mathrm{H} \mathrm{NMR}$ (300 MHz, $\left.\mathrm{CDCl}_{3}\right) \delta 1.35(\mathrm{~d}, 1 \mathrm{H}, J 6.78 \mathrm{~Hz}), 2.58$ (ddd, $1 \mathrm{H}, J 1.65$, 7.60, $17.30 \mathrm{~Hz}), 2.70$ (ddd, 1H, $J 1.70,6.00,17.30 \mathrm{~Hz}$ ), 3.69 (sextet, 1H, J 6.78 Hz), 7.27-7.44 (m, 5H), 9.75 (t, 1H, $J 1.65 \mathrm{~Hz}) ;{ }^{13} \mathrm{C}$ NMR $\left(75 \mathrm{MHz}, \mathrm{CDCl}_{3}\right) \delta 21.1,37.6,50.1$, 127.6, 129.1, 133.0, 133.5, 200.5; MS, $m / z$ (\%), 182 (1), 182 (2), 180 (23), 137 (4), 110 (100), 77 (6.1); $\mathrm{t}_{\mathrm{R}}=12.1 \mathrm{mim}$ [condition A: column temperature: $50^{\circ} \mathrm{C}(5 \mathrm{~min})$ to $280^{\circ} \mathrm{C}$

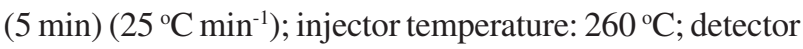
temperature: $280{ }^{\circ} \mathrm{C}$ ].

\section{4-(2-mercaptoethylthio)-4-phenylbutan-2-one (12)}

To $15 \mathrm{~mL}$ of a $0.3 \mathrm{~mol} \mathrm{~L}-1$ aqueous $\mathrm{NaHCO}_{3}$ solution, $5 \mathrm{mmol}$ of ethane-1,2-dithiol (11) were added. Soon after, $5 \mathrm{mmol}$ of benzalacetone (10) were also added. The reaction mixture was then stirred vigorously for $17 \mathrm{~h}$ at room temperature. Then, the reaction mixture was extracted with chloroform. The organic extract was dried (using anhydrous $\mathrm{Na}_{2} \mathrm{SO}_{4}$ ), and the solvent was evaporated under reduced pressure to obtain the pure product. $0.87 \mathrm{~g}$ of the product was obtained. The following spectroscopic data were obtained: ${ }^{1} \mathrm{H} \mathrm{RMN}\left(300 \mathrm{MHz}, \mathrm{CDCl}_{3}\right.$ ) $\delta 1.59$ (bs, 1H), 2.08 (s, $3 \mathrm{H}), 2.55$ (m, 4H), 2.97 (d, J $7.21 \mathrm{~Hz}, 2 \mathrm{H})$, 4.35 (t, J 7.21 Hz, 1H), $7.30(\mathrm{~m}, 5 \mathrm{H}) ;{ }^{13} \mathrm{C} \mathrm{RMN} \mathrm{(50} \mathrm{MHz,}$ $\left.\mathrm{CDCl}_{3}\right) \delta 23.90,30.66,31.06,44.18,49.98,127.66$, 127.75, 128.67, 141.57, 205.05; MS, $m / z$ (\%) 240 (15), 222 (9), 206 (20), 179 (25), 147 (41), 104 (30), 77 (18), $43(100) ; \mathrm{t}_{\mathrm{R}}=20.2 \mathrm{mim}$ [condition $\mathrm{B}$, column temperature: $40{ }^{\circ} \mathrm{C}$ (2 min) to $250{ }^{\circ} \mathrm{C}(15 \mathrm{~min})\left(10{ }^{\circ} \mathrm{C} \mathrm{min}{ }^{-1}\right)$, injector temperature: room temperature (on column), detector temperature: $280{ }^{\circ} \mathrm{C}$ ].

Michael addition of thiophenol (2) to $\alpha, \beta$-unsaturated terpenes

To $10 \mathrm{~mL}$ of a $0.5 \mathrm{~mol} \mathrm{~L}^{-1} \mathrm{NaHCO}_{3}$ aqueous solution, 20 mmol of thiophenol (2) were added. Soon after, $10 \mathrm{mmol}$ of the respective terpene were also added. The reaction mixture was then stirred vigorously for $24 \mathrm{~h}$ at room temperature. The products of each substrate were isolated and characterized as follows:
For $(R)$-carvone (13)

(2S,3R, 5S)-5-Isopropenyl-2-methyl-3-(phenylthio) cyclohexanone (14): The solid product was isolated from the reaction media by filtration and purified by recrystalization using hexane as the solvent; $1.27 \mathrm{~g}$ were obtained. For NMR data, see Table $1\left({ }^{1} \mathrm{H}-300 \mathrm{MHz},{ }^{13} \mathrm{C}-75 \mathrm{MHz}\right)$, $\mathrm{t}_{\mathrm{R}}=20.7 \mathrm{~min}$ [condition A: column temperature: $70{ }^{\circ} \mathrm{C}$ to $250{ }^{\circ} \mathrm{C}(5 \mathrm{~min})\left(8^{\circ} \mathrm{C} / \mathrm{min}\right)$, injector temperature: $220^{\circ} \mathrm{C}$, detector temperature: $250{ }^{\circ} \mathrm{C}$ ]. mp, 63-65 ${ }^{\circ} \mathrm{C}$ (hexane); $[\alpha]_{24}^{D}=-91.0\left(c 10, \mathrm{CH}_{2} \mathrm{Cl}_{2}\right)$.

For (S)-perillaldehyde (15)

( $1 R, 2 R, 4 S)$ - 4 - Is opropeny $1-2$-(phenylthio) cyclohexanecarbaldehyde (16): The solid product was isolated from the reaction media by filtration and crystallized using hexane as the solvent. $1.77 \mathrm{~g}$ of a sample of compound 16 and thiophenol were obtained. In order to obtain a pure sample, this mixture was purified by flash chromatography using hexane: ethyl acetate (9:1); $1.20 \mathrm{~g}$ were obtained. For NMR data, see Table $2\left({ }^{1} \mathrm{H}-400 \mathrm{MHz},{ }^{13} \mathrm{C}-100 \mathrm{MHz}\right)$, $\mathrm{t}_{\mathrm{R}}=20.5 \mathrm{~min}$ [condition A: column temperature: $70^{\circ} \mathrm{C}$ to

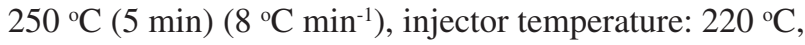
detector temperature: $\left.250^{\circ} \mathrm{C}\right] . \mathrm{mp}, 75-76^{\circ} \mathrm{C}$ (hexane), $[\alpha]$ ${ }_{24}^{D}=-58.0\left(c 10, \mathrm{CH}_{2} \mathrm{Cl}_{2}\right)$.

\section{Results and Discussion}

\section{Synthesis}

In this work, we extended our studies to other $\alpha, \beta$ unsaturated carbonyl compounds.

The reactions of aliphatic acyclic carbonyl compounds like crotonaldehyde (8) with thiophenol (2) and benzalacetone (10) with ethane-1,2-dithiol (11) also yielded Michael addition products (Scheme 3).

Some chiral terpenic substrates for this reaction type were also tested in order to analyze their stereoselectivity in aqueous media. It was observed that thiophenol (2) reacts with $(R)$-carvone (13) and $(S)$-perillaldehyde (15) at $\mathrm{pH} 7$, leading to the kinetic products shown in Scheme 4.

The stereochemistry of these reactions is controlled by the axial addition of thiophenol in the first step and by the axial protonation in the next step (Scheme 5).

These reactions (Scheme 4) are reported in the literature using $\mathrm{CH}_{2} \mathrm{Cl}_{2}$ or hexane at $0^{\circ} \mathrm{C}$ as the solvent and triethylamine as the catalyst, leading to the same products. ${ }^{41,42}$ However, in the literature, the determination of the stereochemistry of the products was not clear. We report here the unambiguous elucidation of the stereochemistry of $\mathbf{1 4}$ and $\mathbf{1 6}$. 


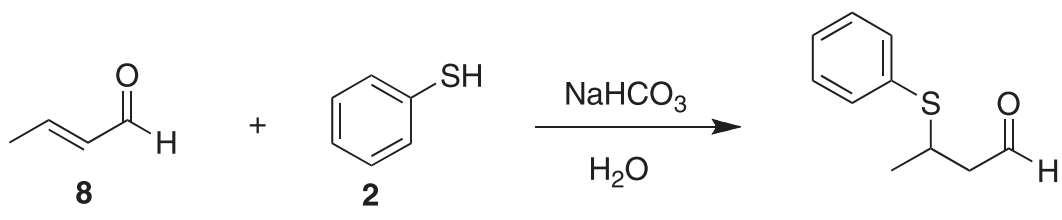

\section{$976 \%$}<smiles>CC(=O)/C=C/c1ccccc1</smiles>

Scheme 3. Michael addition in water.<smiles>Sc1ccccc1</smiles><smiles>C=C(C)[C@H]1CC=C(C)C(=O)C1</smiles>

13<smiles>C=C(C)[C@@H]1CC(=O)[C@H](C)[C@H](Sc2ccccc2)C1</smiles>

14<smiles>C=C(C)[C@@H]1CC[C@@H](C=O)[C@H](Sc2ccccc2)C1</smiles>

16

Scheme 4. Stereoselectivity of Michael addition in water.

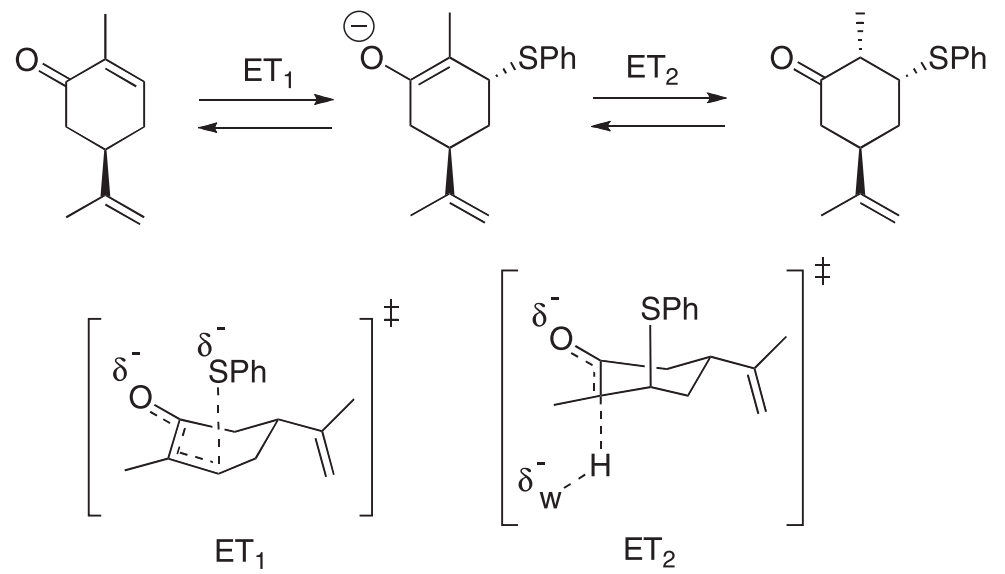

Scheme 5. Transitions states in the formation of compound $\mathbf{1 4}$. 
The methodology developed in this paper presents as an advantage the substitution of a toxic and inflammable organic solvent for water. Furthermore, no temperature control was necessary. Also, in operational work-up, our methodology reduces the product isolation procedure to a filtration step, as these products are insoluble in water.

Stereochemical elucidation with unambiguous spectral assignments of compounds 14 and 16 by NMR

The ${ }^{1} \mathrm{H}$ NMR spectrum for compound $\mathbf{1 6}$ was fully assigned by a combination of homo- and heteronuclear 2D NMR methods, including DQF-COSY, HSQC, HMBC, nOe experiments and 1D-TOCSY. Some important details of the experiments will be commented on.

(2S,3R,5S)-5-Isopropenyl-2-methyl-3-(phenylthio)cyclohexanone (14)

The ${ }^{1} \mathrm{H}$ and ${ }^{13} \mathrm{C}$ NMR assignments of compound $\mathbf{1 4}$ are listed in Table 1. The DQF-COSY experiment of compound 14 demonstrates that $\mathrm{H}-2$ at $\delta 2.89$ (qdd) shows cross signals with the methyl $\mathrm{H}-10$ at $\delta 1.22$ (d) and $\mathrm{H}-3$ at $\delta$ 3.9 (bdt). The H-3 hydrogen shows cross signals with $\mathrm{H}-2$, $\mathrm{H}-4_{\text {eq }}$ at $\delta 2.06$ (dtd) and $\mathrm{H}-4_{\text {ax }}$ at $\delta 1.89$ (ddd) (Figure 1).

In the nOe difference experiment, the relative configuration of the $\mathrm{H}-2$ and $\mathrm{H}-3$ hydrogens was
Table 1. Summary of the ${ }^{1} \mathrm{H}$ and ${ }^{13} \mathrm{C}$ data for compound $\mathbf{1 4}$<smiles>CC=C(C)C1CC(=O)[C@H](C)CC1Sc1ccccc1</smiles>

\begin{tabular}{|c|c|c|}
\hline Assignment & $\delta^{1} \mathrm{H}(\mathrm{J} / \mathrm{Hz})$ & $\delta^{13} \mathrm{C}$ \\
\hline 1 & -- & 209.6 \\
\hline 2 & $2.89\left(\mathrm{qdd}, J_{2-10} 6.73, J_{2-3} 4.80, J_{2-6 \mathrm{ax}} 1.15,1 \mathrm{H}\right)$ & 48.2 \\
\hline 3 & 3.9 (bdt, $J_{3-2} 4.80, J_{3-4 \mathrm{eq}} \approx J_{3-4 a x} 3.50,1 \mathrm{H}$ ) & 53.2 \\
\hline 4 eq & $\begin{array}{l}2.06\left(\mathrm{dtd}, J_{4 \mathrm{eq}-4 \mathrm{ax}} 13.85, J_{4 \mathrm{eq}-\mathrm{z}} \approx J_{4 \mathrm{eq}-5} 3.65, J_{\text {4eq-6eq }}\right. \\
2.06,1 \mathrm{H})\end{array}$ & 35.0 \\
\hline 4 ax & $\begin{array}{l}1.89\left(\mathrm{ddd}, J_{\text {4ax-4eq }} 13.85, J_{\text {4ax-5 }} 11.60, J_{\text {4ax-3 }}\right. \\
3.13,1 \mathrm{H})\end{array}$ & \\
\hline 5 & $\begin{array}{l}3.03 \text { (btt, } J_{5-\text {-ax }} \approx J_{5-\text {-ax }} 12.05, J_{5-4 \mathrm{eq}} \approx J_{5-\text { - } \mathrm{eq}} 3.85 \text {, } \\
1 \mathrm{H})\end{array}$ & 40.1 \\
\hline 6 eq & $\begin{array}{l}2.53\left(\mathrm{ddd}, J_{6 \mathrm{eq}-6 \mathrm{ax}} 13.70, J_{6 \mathrm{eq}-5} 4.30, J_{6 \mathrm{eq}-\mathrm{eq}}\right. \\
2.06,1 \mathrm{H})\end{array}$ & 45.7 \\
\hline 6 ax & $\begin{array}{l}2.28\left(\mathrm{ddd}, J_{6 a x-6 e q} 13.70, J_{6 \text { ax }-5} 12.53, J_{6 a x-2}\right. \\
1.15,1 \mathrm{H})\end{array}$ & \\
\hline 7 & -- & 146.7 \\
\hline $8 \mathrm{a}$ & $\begin{array}{l}4.76 \text { (app quint d, } J_{8 \mathrm{a}-9}=J_{8 \mathrm{a}-5} 1.38, J_{8 \mathrm{a}-\mathrm{-b}} 0.44 \text {, } \\
1 \mathrm{H} \text { ) }\end{array}$ & 109.9 \\
\hline $8 b$ & $4.69-4.72(\mathrm{~m}, 1 \mathrm{H})$ & \\
\hline 9 & $1.66(\operatorname{app~d}, J 0.60,3 \mathrm{H})$ & 20.6 \\
\hline 10 & $1.22\left(\mathrm{~d}, J_{10-2} 6.73,3 \mathrm{H}\right)$ & 12.6 \\
\hline 11 & -- & 134.3 \\
\hline 12 & $7.38-7.43(\mathrm{~m}, 2 \mathrm{H})$ & 132.3 \\
\hline $13 / 14$ & 7.21-7.33 (m, 3H) & $\begin{array}{l}128.9 \\
127.2\end{array}$ \\
\hline
\end{tabular}

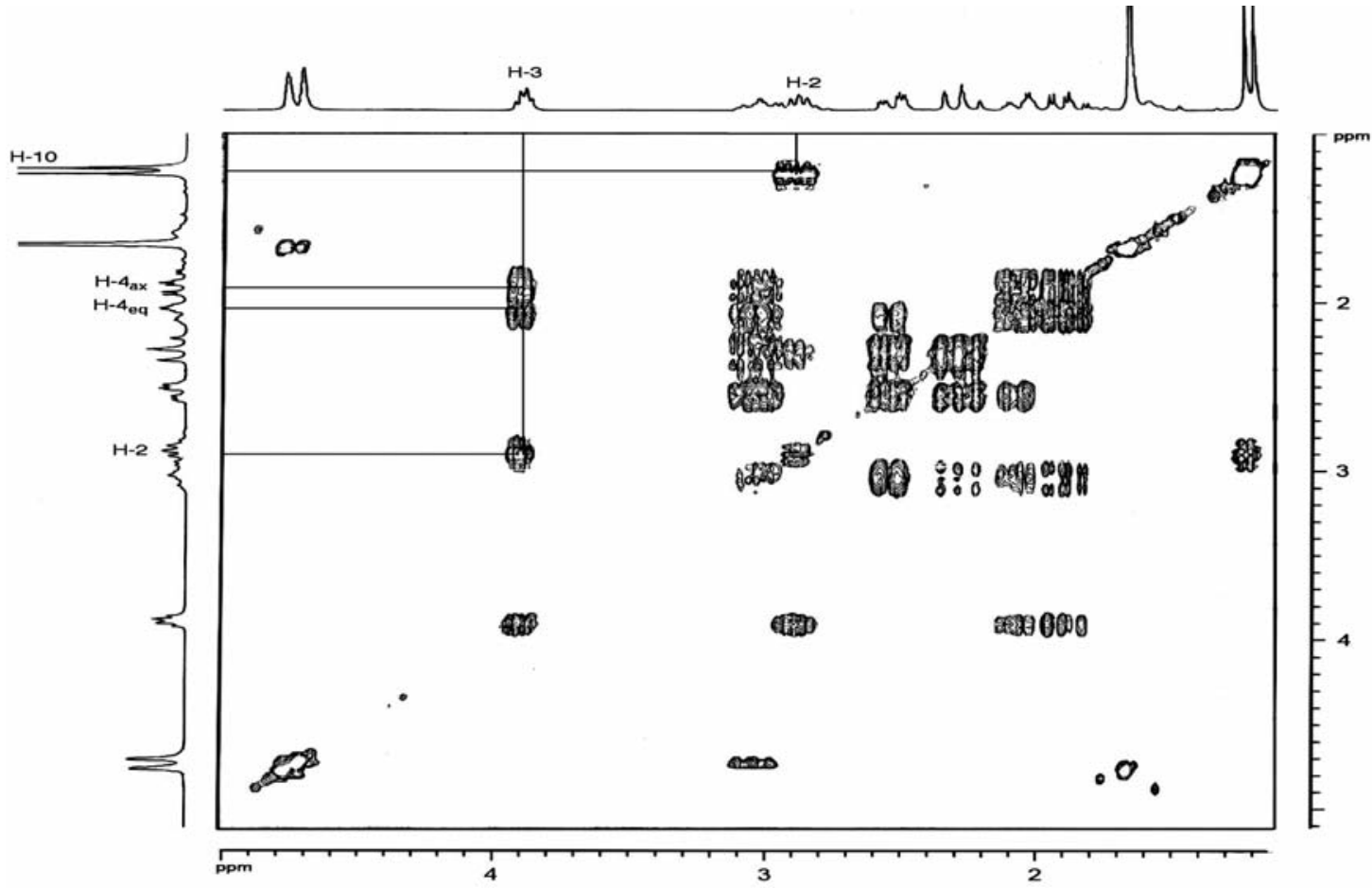

Figure 1. COSY spectra showing cross signals in chloroform for compound $\mathbf{1 4}$. 
established. The selective irradiation of $\mathrm{H}-2$ produces nOe enhancements at $\mathrm{H}-3$ and $\mathrm{H}-10$, and a slight effect at axial hydrogens H-6 and H-4, while the selective saturation of $\mathrm{H}-3$ produces nOe enhancements at $\mathrm{H}-2$ and both $\mathrm{H}-4$ and $\mathrm{H}-10$. The nOe effect on axial and equatorial hydrogen $\mathrm{H}-4$ is very similar. These nOe indicate that hydrogen $\mathrm{H}-3$ is at the equatorial position, because if it were in the axial position this difference would be greater (Figure 2).
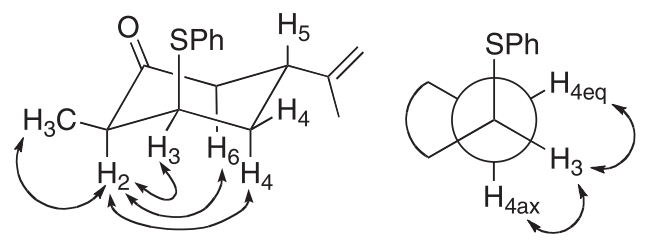

Figure 2. nOe for compound 14.

(1R,2R,4S)-4-isopropenyl-2-(phenylthio)cyclohexanecarbaldehyde (16)

The determination of the stereochemistry of compound 16 was only possible with a NMR study in $\mathrm{CDCl}_{3}$ and $\mathrm{C}_{6} \mathrm{D}_{6}$ (Table 2).

In $\mathrm{CDCl}_{3}$ (Figure 3a), the $\mathrm{H}-2$ and $\mathrm{H}-5$ hydrogens are overlapped as a multiplet in 2.49-2.58 dby DQF-COSY spectrum (Figure 4). On the other hand, in $\mathrm{C}_{6} \mathrm{H}_{6}$ (Figure $3 \mathrm{~b}), \mathrm{H}-5$ appears as a triplet of triplets in $2.50 \mathrm{~d}\left(J_{5-4 \mathrm{eq}} \approx J_{5 \text {-6eq }}\right.$ $3.10 \mathrm{~Hz}, J_{5-4 \mathrm{ax}} \approx J_{5-6 \mathrm{ax}} 12.00 \mathrm{~Hz}$ ), but the $\mathrm{H}-2$ is overlapped with $\mathrm{H}-7$ eq in $1.77-1.88 \mathrm{~d}(\mathrm{~m}, 2 \mathrm{H})$.

With the TOCSY experiment, it was possible to determine the multiplicity of hydrogen $\mathrm{H}-2$ ( $\delta$ 2.49-2.58). Hydrogen $\mathrm{H}-3$ ( $\delta$ 3.98) was selectively saturated in $\mathrm{CDCl}_{3}$. The spectrum was obtained with a mixing time of $25 \mathrm{~ms}$ at $20^{\circ} \mathrm{C}$. The irradiation changes the multiplet to a double triplet with $J_{2-7 \mathrm{ax}} 12.37 \mathrm{~Hz}$ and $J_{2-7 \mathrm{eq}} \approx J_{2-3} 3.10 \mathrm{~Hz}$ (Figure 5). These couplings are consistent with $\mathrm{H}-2$ in the axial position.

Finally, the relative configurations of $\mathrm{H}-3$ and $\mathrm{H}-5$ were examined with ${ }^{1} \mathrm{H}$ nOe difference spectroscopy. Saturation of $\mathrm{H}-3$ in $\mathrm{CDCl}_{3}$ produces nOe enhancements at $\mathrm{H}-2$ and $\mathrm{H}-4$ axial, while the saturation of $\mathrm{H}-5$ in the $\mathrm{C}_{6} \mathrm{D}_{6}$ solvent shows nOe at $\mathrm{H}-4$ equatorial. With this result, it is possible to suggest that H-3 and H-2 are synclinal, as shown in Figure 6.

\section{Conclusions}

The present work is an additional relevant contribution to the study of organic reactions in water. The Michael addition reactions of thiophenol to $\alpha, \beta$-unsaturated terpenes in aqueous media show high stereoselectivity in the formation of the products at room temperature, with

Table 2. Summary of the ${ }^{1} \mathrm{H}$ and ${ }^{13} \mathrm{C}$ data for compound $\mathbf{1 6}$

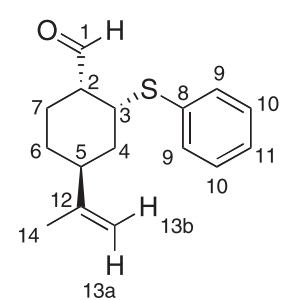

\begin{tabular}{|c|c|c|c|c|}
\hline \multirow{2}{*}{ Assig. } & \multicolumn{2}{|l|}{$\mathrm{CDCl}_{3}$} & \multicolumn{2}{|l|}{$\mathrm{C}_{6} \mathrm{D}_{6}$} \\
\hline & $\delta{ }^{1} \mathrm{H}(J / \mathrm{Hz})$ & $\delta{ }^{13} \mathrm{C}$ & $\delta^{1} \mathrm{H}(J / \mathrm{Hz})$ & $\delta{ }^{13} \mathrm{C}$ \\
\hline 1 & $9.70(\mathrm{~s}, 1 \mathrm{H})$ & 202.4 & $9.48(\mathrm{~s}, 1 \mathrm{H})$ & 200.7 \\
\hline 2 & $2.49-2.58(\mathrm{~m}, 1 \mathrm{H})$ & 53.1 & $1.77-1.88(\mathrm{~m}, 1 \mathrm{H})$ & 53.0 \\
\hline 3 & $3.98\left(\right.$ app dd, $\left.J_{3-4 \mathrm{eq}} 5.97 J_{3-4 \mathrm{ax}} \approx J_{3-2} 3.10,1 \mathrm{H}\right)$ & 48.0 & $3.52\left(\right.$ app dd, $\left.J_{3-4 \mathrm{eq}} 5.98, J_{3-4 \mathrm{ax}} \approx J_{3-2} 3.33,1 \mathrm{H}\right)$ & 48.2 \\
\hline 4 ax. & $1.63\left(\mathrm{ddd}, J_{4 \mathrm{ax}-4 \mathrm{eq}} 13.50, J_{4 \mathrm{ax}-5} 12.11, J_{4 \mathrm{ax}-3} 3.35,1 \mathrm{H}\right)$ & 367 & $1.20\left(\mathrm{ddd}, J_{4 \mathrm{ax}-4 \mathrm{eq}} 13.40, J_{4 \mathrm{ax}-5} 12.00, J_{4 \mathrm{ax}-3} 3.33,1 \mathrm{H}\right)$ & 369 \\
\hline 4 eq. & $2.08\left(\mathrm{ddd}, J_{4 \mathrm{eq}-4 \mathrm{ax}} 13.50, J_{4 \mathrm{eq}-3} 5.14, J_{4 \mathrm{eq}-5} 3.10,1 \mathrm{H}\right)$ & 30.1 & $1.92\left(\mathrm{ddd}, J_{4 \mathrm{eq}-4 \mathrm{ax}} 13.40, J_{4 \mathrm{eq}-3} 5.10, J_{4 \mathrm{eq}-5} 3.10,1 \mathrm{H}\right)$ & 30. \\
\hline 5 & $2.49-2.58(\mathrm{~m}, 1 \mathrm{H})$ & 39.0 & $2.50\left(\mathrm{tt}, J_{5-4 \mathrm{eq}} \approx J_{5-6 \mathrm{eq}} 3.10, J_{5-4 \mathrm{ax}} \approx J_{5-6 \mathrm{ax}} 12.00,1 \mathrm{H}\right)$ & 39.3 \\
\hline $\begin{array}{l}6 \text { ax. } \\
6 \text { eq. }\end{array}$ & $\begin{array}{l}1.22\left(\mathrm{qd}, J_{6 \mathrm{ax}-6 \mathrm{eq}} \approx J_{6 \mathrm{ax}-5} \approx J_{6 \mathrm{ax}-7 \mathrm{ax}} 12.70, J_{6 \mathrm{ax}-7 \mathrm{eq}} 3.65,1 \mathrm{H}\right) \\
1.98-2.05(\mathrm{~m}, 1 \mathrm{H})\end{array}$ & 30.0 & $\begin{array}{l}0.86\left(\mathrm{qd}, J_{6 \mathrm{ax}-6 \mathrm{eq}} \approx J_{6 \mathrm{ax}-5} \approx J_{6 \mathrm{ax}-7 \mathrm{ax}} 12.20, J_{6 \mathrm{ax}-7 \mathrm{eq}} 3.60,1 \mathrm{H}\right) \\
1.63-1.72(\mathrm{~m}, 1 \mathrm{H})\end{array}$ & 30.2 \\
\hline $\begin{array}{l}7 \text { eq. } \\
7 \text { ax. }\end{array}$ & $1.91-2.03(\mathrm{~m}, 2 \mathrm{H})$ & 21.8 & $\begin{array}{l}1.77-1.88(\mathrm{~m}, 1 \mathrm{H}) \\
1.63-1.72(\mathrm{~m}, 1 \mathrm{H})\end{array}$ & 22.1 \\
\hline 8 & -- & 135.2 & -- & 135.9 \\
\hline 9 & $7.41-7.46(\mathrm{~m}, 2 \mathrm{H})$ & 132.4 & $7.27-7.73(\mathrm{~m}, 2 \mathrm{H})$ & 132.6 \\
\hline 10 & $7.19-7.34(\mathrm{~m} .3 \mathrm{H})$ & 127.5 & $6.80-7.07(\mathrm{~m} .3 \mathrm{H})$ & 127.5 \\
\hline 11 & $1.19-1.54(\mathrm{~m}, \mathrm{3H})$ & 129.1 & $0.00-1.07(\mathrm{~m}$, , गп) & 129.2 \\
\hline 12 & -- & 149.1 & -- & 149.3 \\
\hline $\begin{array}{l}13 \mathrm{a} \\
13 \mathrm{~b}\end{array}$ & $\begin{array}{l}4.73\left(\text { app quint, } J_{13 \mathrm{a}-14} \approx J_{13 \mathrm{a}-5} 1.30,1 \mathrm{H}\right) \\
4.71(\operatorname{app~s}, 1 \mathrm{H})\end{array}$ & 109.1 & $\begin{array}{l}4.75\left(\operatorname{app} q u i n t, J_{13 \mathrm{a}-14} \approx J_{13 \mathrm{a}-5} 1.38,1 \mathrm{H}\right) \\
4.71(\operatorname{app~s}, 1 \mathrm{H})\end{array}$ & 109.3 \\
\hline 14 & $1.72(\mathrm{bs}, 3 \mathrm{H})$ & 21.2 & $1.56(\mathrm{~s}, 3 \mathrm{H})$ & 21.1 \\
\hline
\end{tabular}




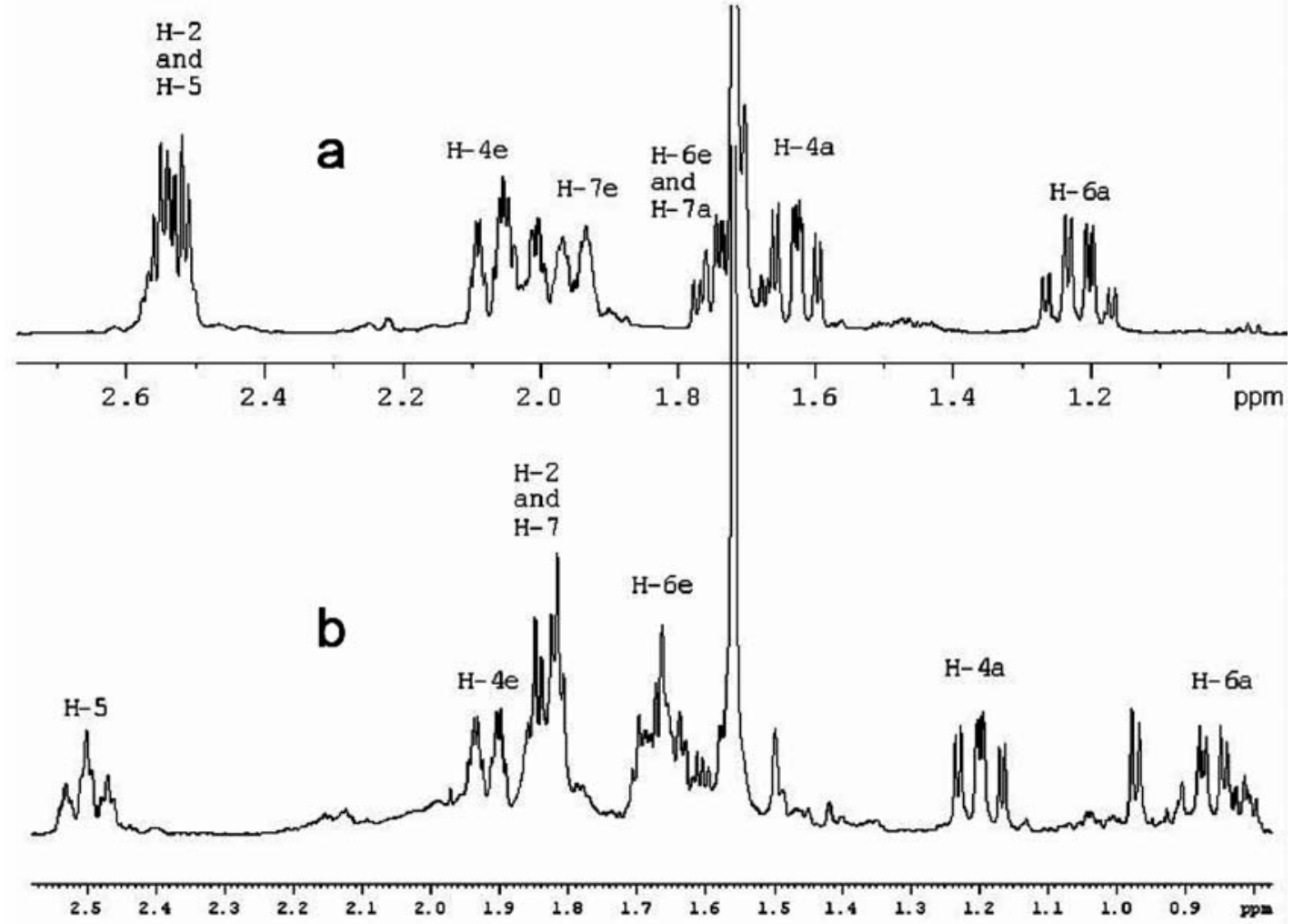

Figure 3. ${ }^{1} \mathrm{H}$ NMR spectra of compound 16 in (a) a chloroform solvent and (b) a benzene solvent.

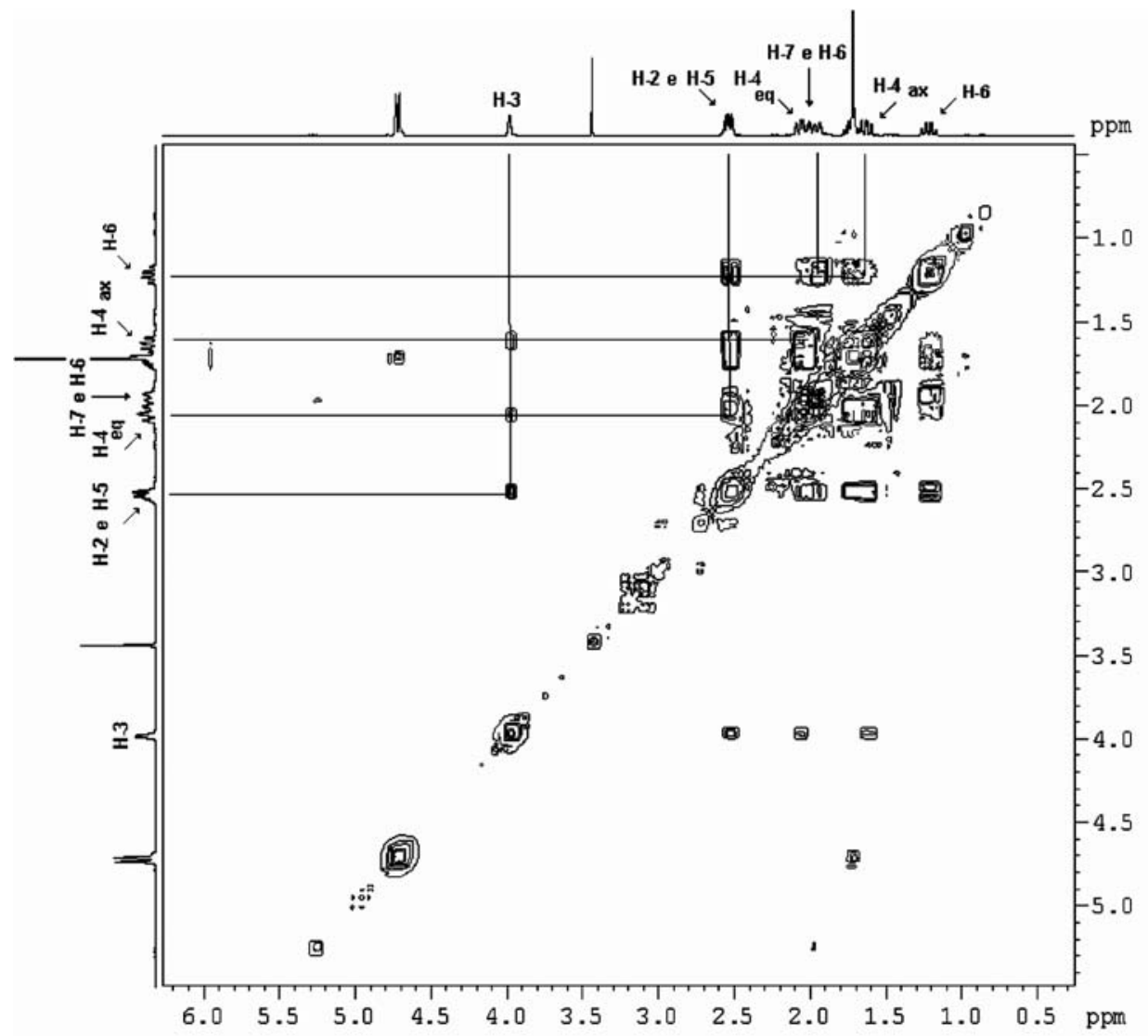

Figure 4. COSY spectra showing a cross signals for compound $\mathbf{1 6}$ in a chloroform solvent. 


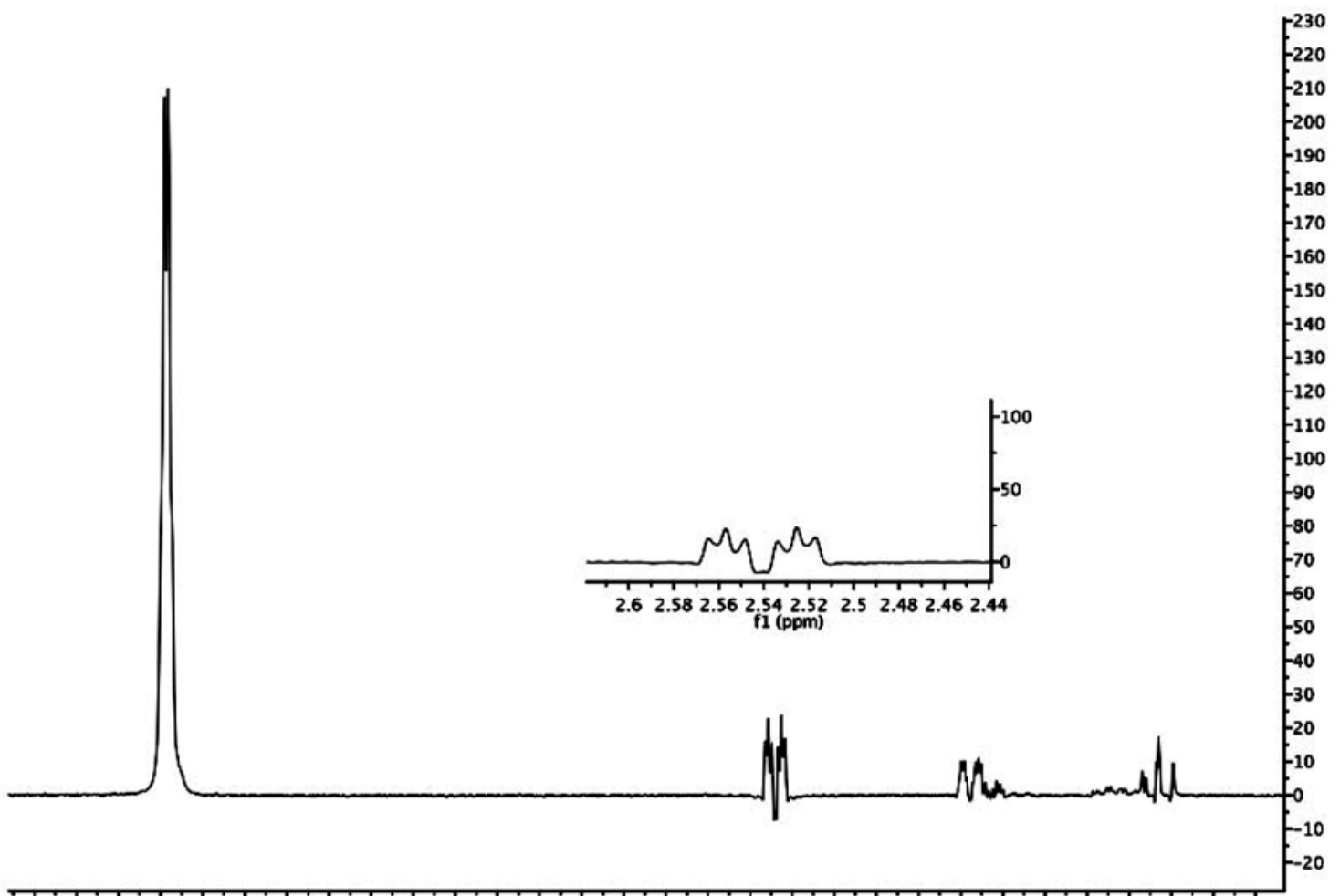

$\begin{array}{llllllllllllllllllllllllllllllll}4.3 & 4.2 & 4.1 & 4 & 3.9 & 3.8 & 3.7 & 3.6 & 3.5 & 3.4 & 3.3 & 3.2 & 3.1 & 3 & 2.9 & 2.8 & 2.7 & 2.6 & 2.5 & 2.4 & 2.3 & 2.2 & 2.1 & 2 & 1.9 & 1.8 & 1.7 & 1.6 & 1.5 & 1.4\end{array}$

Figure 5. Selective excitation of hydrogen $\mathrm{H}-3$ in the TOCSY experiment.

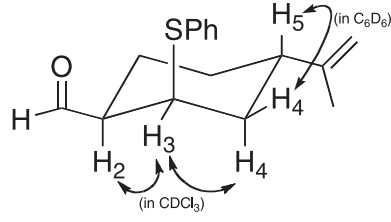

Figure 6. nOe for compound 16.

good yields. This methodology represents an improvement over previous methods available in the literature in that it: a) uses a non-aggressive solvent; b) substitutes $\mathrm{NaHCO}_{3}$ for triethylamine as the base; c) can be carried out at room temperature (while in previous procedures low temperatures were needed); and d) the isolation step was reduced to a simple filtration. All of these advantages show progress toward the goal of Green Chemistry.

\section{Supplementary Information}

NMR spectra for the compounds $\mathbf{1 4}$ and $\mathbf{1 6}$ are available free of charge as PDF file at http://jbcs.sbq.org.br.

\section{Acknowledgments}

We thank CNPq and CAPES for financial support.

\section{References}

1. Bezerra, M. C. L.; Bursztyn, M.; Ciência e Tecnologia para Desenvolvimento Sustentável, Ministério do Meio Ambiente, Instituto Brasileiro do Meio Ambiente e dos Recursos Naturais Renováveis, Consórcio CDS/UNB/Abipti, Ed. IBAMA: Brasília, 2000.

2. Anastas, P. T.; Warner, J. C.; Green Chemistry: Theory and Practice, Oxford University Press: Great Britain, 2000.

3. da Silva, F. M.; Lacerda, P. S. B.; Jones Jr., J.; Quim. Nova 2005, $28,103$.

4. Prado, A. G. S.; Quim. Nova 2003, 26, 738.

5. Merat, L. M. O. C.; San Gil, R. A. S.; Quim. Nova 2003, 26, 779.

6. Lenardão, E. J.; Freitag, R. A.; Dabdoub, M. J.; Batista, A. C. F.; Silveira, C. C.; Quim. Nova 2003, 26, 123.

7. Dupont, J.; Quim. Nova 2000, 23, 825.

8. "wwverde" - www.ufpel.tche.br/iqg/wwverde - accessed in February 2008.

9. Breslow, R.; Acc. Chem. Res. 1991, 24, 6.

10. Grieco, P. A.; Organic Synthesis in Water, Blacki Academic \& Professional: London, 1998.

11. Li, C. -H.; Chan, T. -H.; Organic Reaction in Aqueous Media, John Wiley \& Sons, Inc.: New York, 1997.

12. Katritzky, A. R.; Allin, S. M.; Acc. Chem. Res. 1996, 29, 399. 
13. da Silva, F. M.: Jones Jr., J.; Quim. Nova 2001, 24, 646.

14. Bergmann, E. D.; Ginsburg, D.; Pappo, R.; Organic Reactions: The Michael Reaction, John Wiley \& Sons, Inc.: London, 1959, Vol. 10.

15. Keller, E.; Feringa, B. L.; Tetrahedron Lett. 1996, 37, 1879.

16. Keller, E.; Feringa, B. L.; Synlett 1997, 842.

18. Mori Y.; Kakumoto, K.; Manabe, K.; Kobayashi,S.; Tetrahedron Lett. 2000, 41, 3107.

19. Loh, T. -P.; Wei L. -L.; Synlett 1998, 975.

20. Ding, R.; Katebzadeh, K.; Roman, L.; Bergquist, K.; Lindström, U. M.; J. Org. Chem. 2006, 71, 352.

21. Chaudhuri, M. K; Hussain, S.; J. Mol. Cat. A 2007, 269, 214.

22. Balline, R; Bosica, G.; Tetrahedron Lett. 1996, 37, 8027.

23. Bensa, D.; Brunel, J. -M.; Buono, G.; Rodriguez, J.; Synlett 2001, 715 .

24. Shimizu, S.; Shirakawa, S.; Suzuki, T.; Sasaki, Y.; Tetrahedron 2001, 57, 6169.

25. Balline, R.; Barboni, G.; Bosica, G.; Filippone, P.; Peretti, S.; Tetrahedron 2000, 56, 4095.

26. Balline, R.; Barboni, L.; Giarlo, G.; J. Org. Chem. 2003, 68, 9173.

27. Naidu, B. N.; Sorenson, M. E.; Bronson, J. J.; Pucci, M. J.; Clark, J. M.; Ueda, Y.; Bioorg. Med. Chem. Lett. 2005, 15, 2069.

28. Shibatomi, K.; Nakahashi, T.; Uozumi, Y.; Synlett 2000, 1643.

29. Lubineau, A.; Augé, J.; Tetrahedon Lett. 1992, 33, 8073.
30. Hajos, Z. G.; Parrish, D. R.; J. Org. Chem. 1974, 39, 1612.

31. Harada, N.; Sugioka, T.; Uda, H.; Kuriki, T.; Synthesis 1990, 53.

32. Naidu, B. N.; Li, W.; Sorenson, M. E.; Connolly, T. P.; Wichtowski, J. A.; Zhang, Y.; Kim, O. K.; Matiskella, J. D.; Lam, K. S.; Bronson, J. J.; Ueda, Y.; Tetrahedron Lett. 2004, $45,1059$.

33. Petrier, C; Dupy, C.; Luche, J. L.; Tetrahedron 1986, 27, 3149.

34. Luche, J. L.; Allavenda, C.; Tetrahedron 1988, 29, 5369.

35. Luche, J. L.; Allavenda, C.; Petrier, C.; Dupuy, C.; Tetrahedron 1992, 29, 5373.

36. Suárez, R. M.; Sestelo, J. P.; Sarandeses, L. A.; Chem. Eur. J. 2003, 9, 4179 .

37. da Silva, F. M.; Gomes, A. K.; Jones Jr., J.; Can. J. Chem. 1999, $77,624$.

38. da Silva, F. M.: Jones Jr., J.; J. Braz. Chem. Soc. 2001, 12, 135

39. Lindström, U. M.; Chem. Rev. 2002, 102, 2751.

40. King, J. F.; Rathore, R.; Lam, J. Y. L.; Guo, Z. R.; Klassen, D. F.; J. Am. Chem. Soc. 1992, 114, 3028.

41. Solladie, G.; Hutt, J.; Bull. Soc. Chim. Fr. 1986, 4, 643.

42. Smitt, O; Högberg, H. -E.; J. Chem. Res. (S), 2002, 527.

Received: May 9, 2007

Web Release Date: April 18, 2008 
Michael Additions of Thiocompounds to $\alpha, \beta$-Unsaturated Carbonyl Compounds in Aqueous Media: Stereoselectivity with Unambiguous Characterization by NMR

Queli Aparecida Rodrigues de Almeida, ${ }^{a}$ Maria Luiza de Oliveira Pereira, ${ }^{a}$ Ricardo Bezerra Coelho, ${ }^{a}$ Erika Martins de Carvalho, ${ }^{b}$ Carlos Roland Kaiser, ${ }^{a}$ Joel Jones Junior ${ }^{*, a}$ and Flavia Martins da Silva ${ }^{*, a}$

${ }^{a}$ Departamento de Química Orgânica, Instituto de Química, Universidade Federal do Rio de Janeiro, CP 68.584, 21941-972 Rio de Janeiro-RJ, Brazil

${ }^{b}$ Instituto de Tecnologia em Fármacos, Far-Manguinhos, Rua Sizenando Nabuco no.100, Manguinhos, 21041-250 Rio de Janeiro-RJ, Brazil

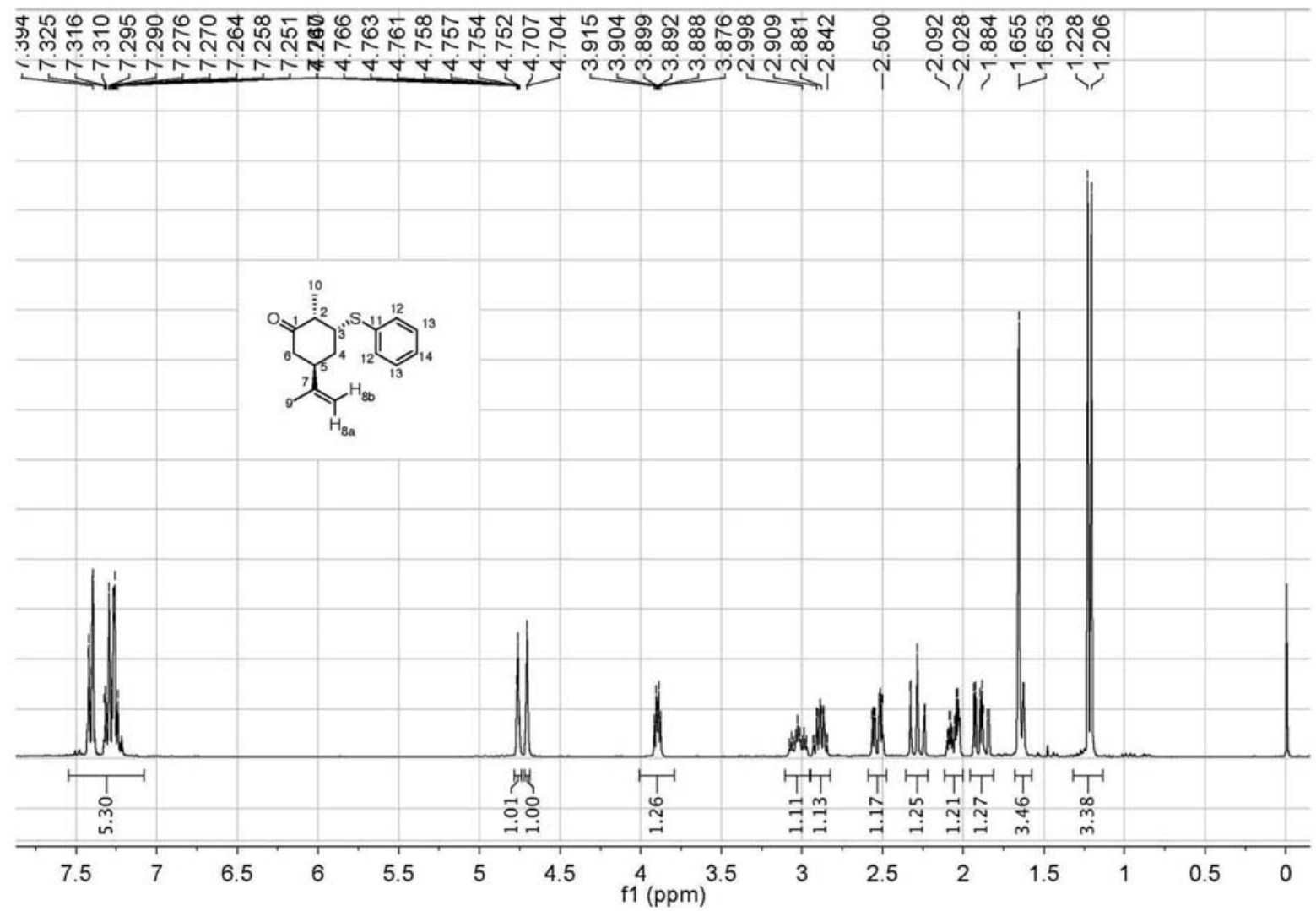

Figure S1. ${ }^{1} \mathrm{H}$ NMR spectrum of compound $\mathbf{1 4}\left(400 \mathrm{MHz}, \mathrm{CDCl}_{3}\right)$. 


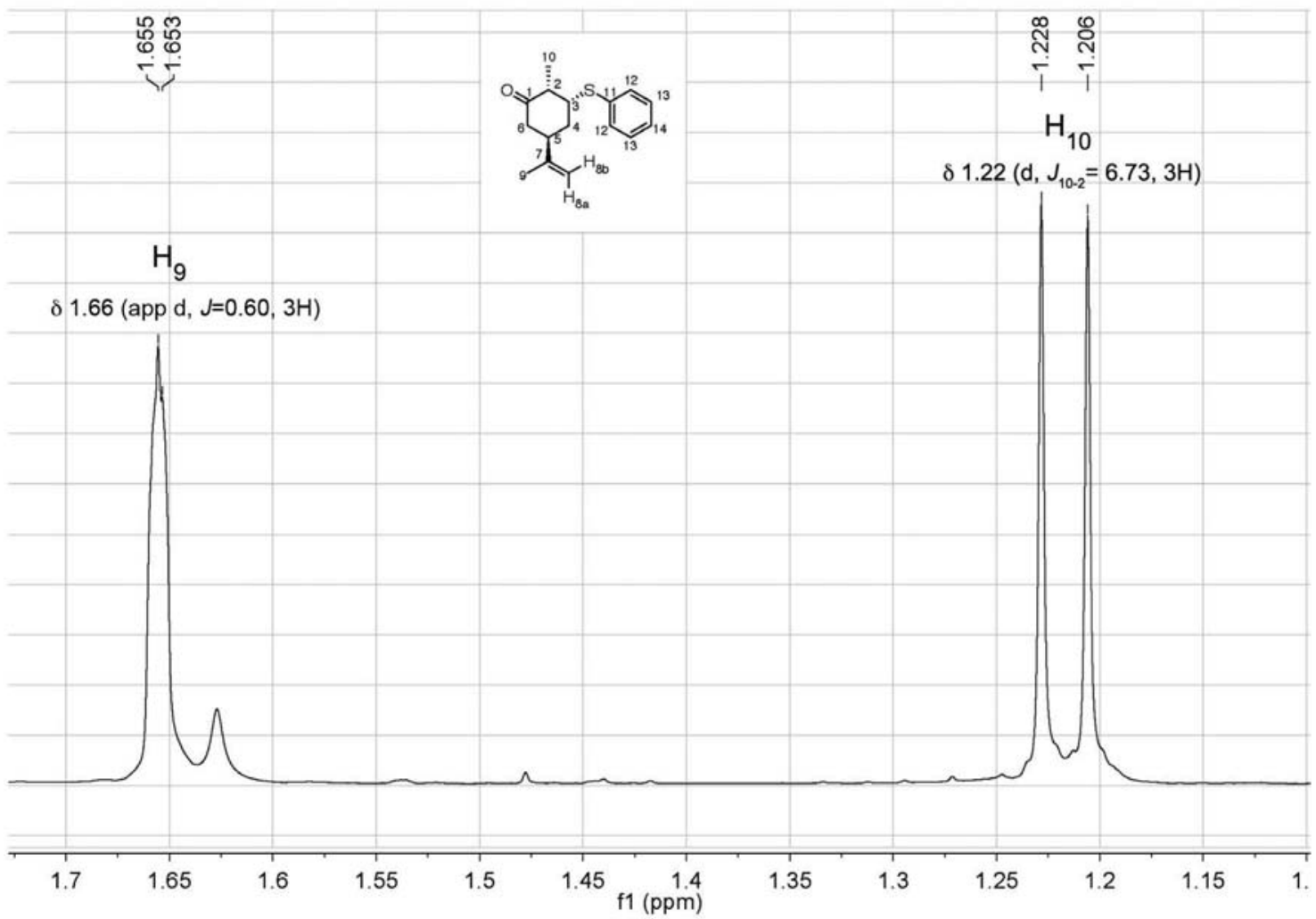

Figure S2. ${ }^{1} \mathrm{H}$ NMR spectrum of compound 14 between $\delta 1.15-1.70\left(400 \mathrm{MHz}, \mathrm{CDCl}_{3}\right)$.
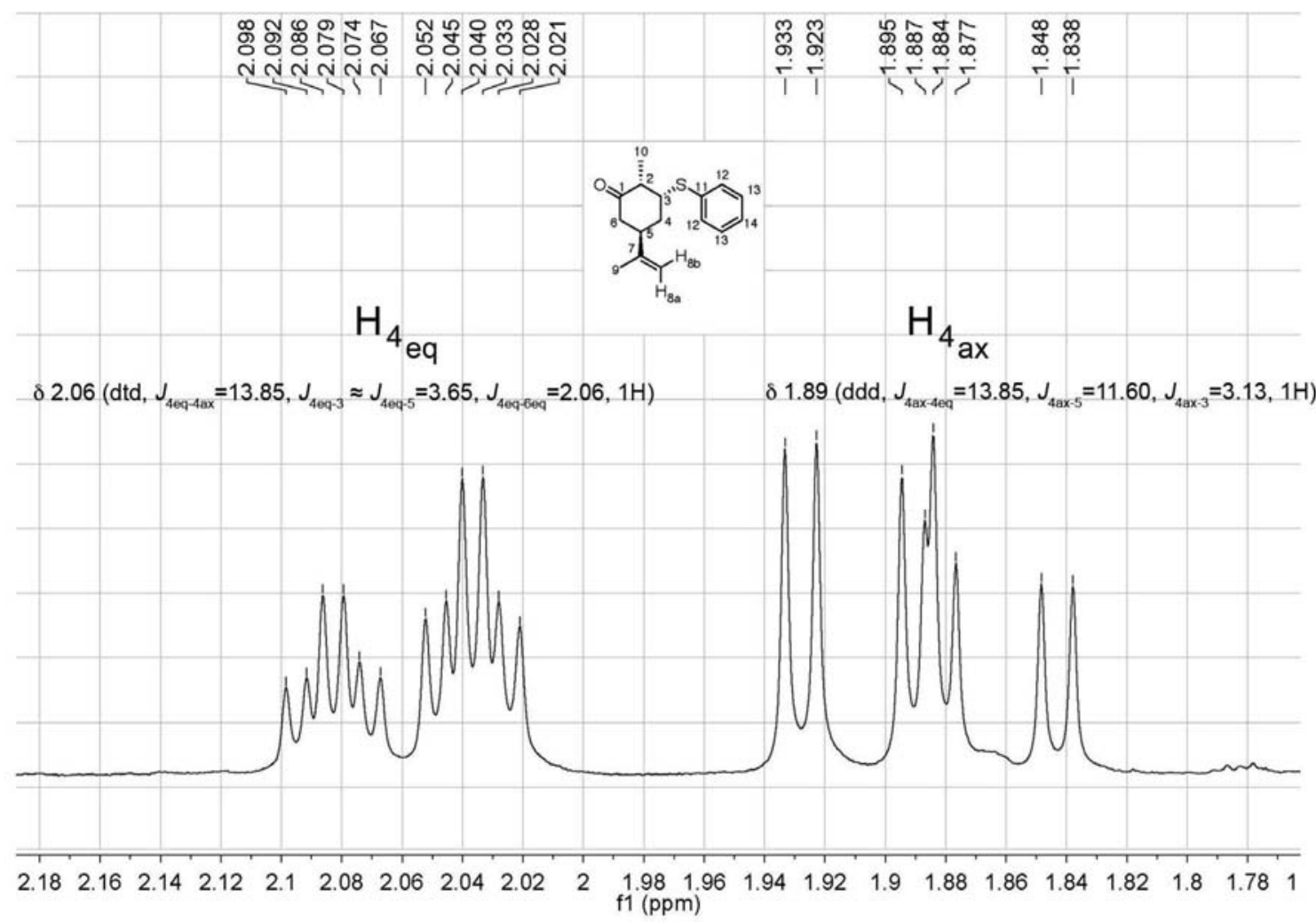

Figure S3. ${ }^{1} \mathrm{H}$ NMR spectrum of compound 14 between $\delta 1.78-2.18\left(400 \mathrm{MHz}, \mathrm{CDCl}_{3}\right)$. 


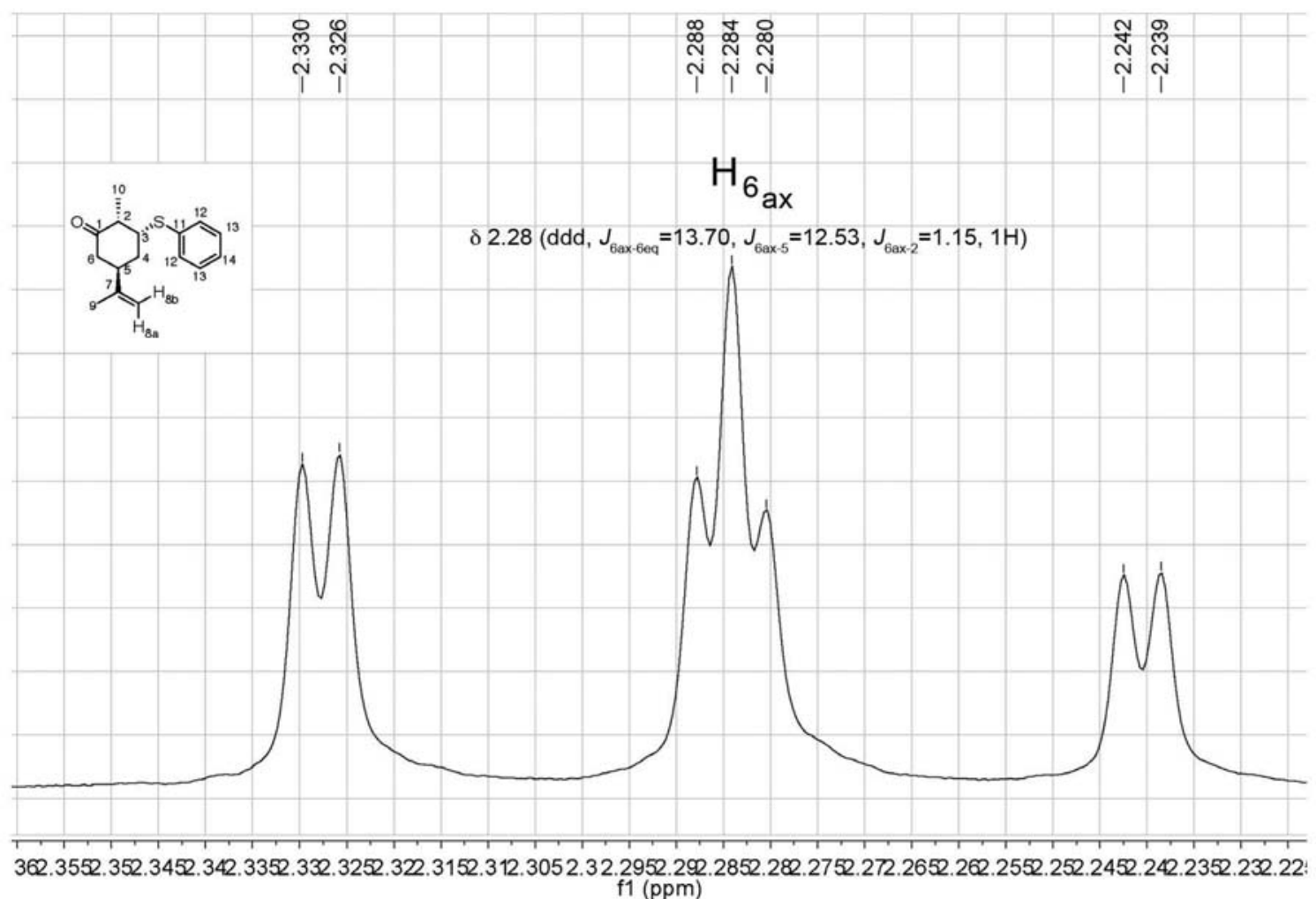

Figure S4. ${ }^{1} \mathrm{H}$ NMR spectrum of compound 14 between $\delta 2.22-2.35$ (400 $\left.\mathrm{MHz}, \mathrm{CDCl}_{3}\right)$.

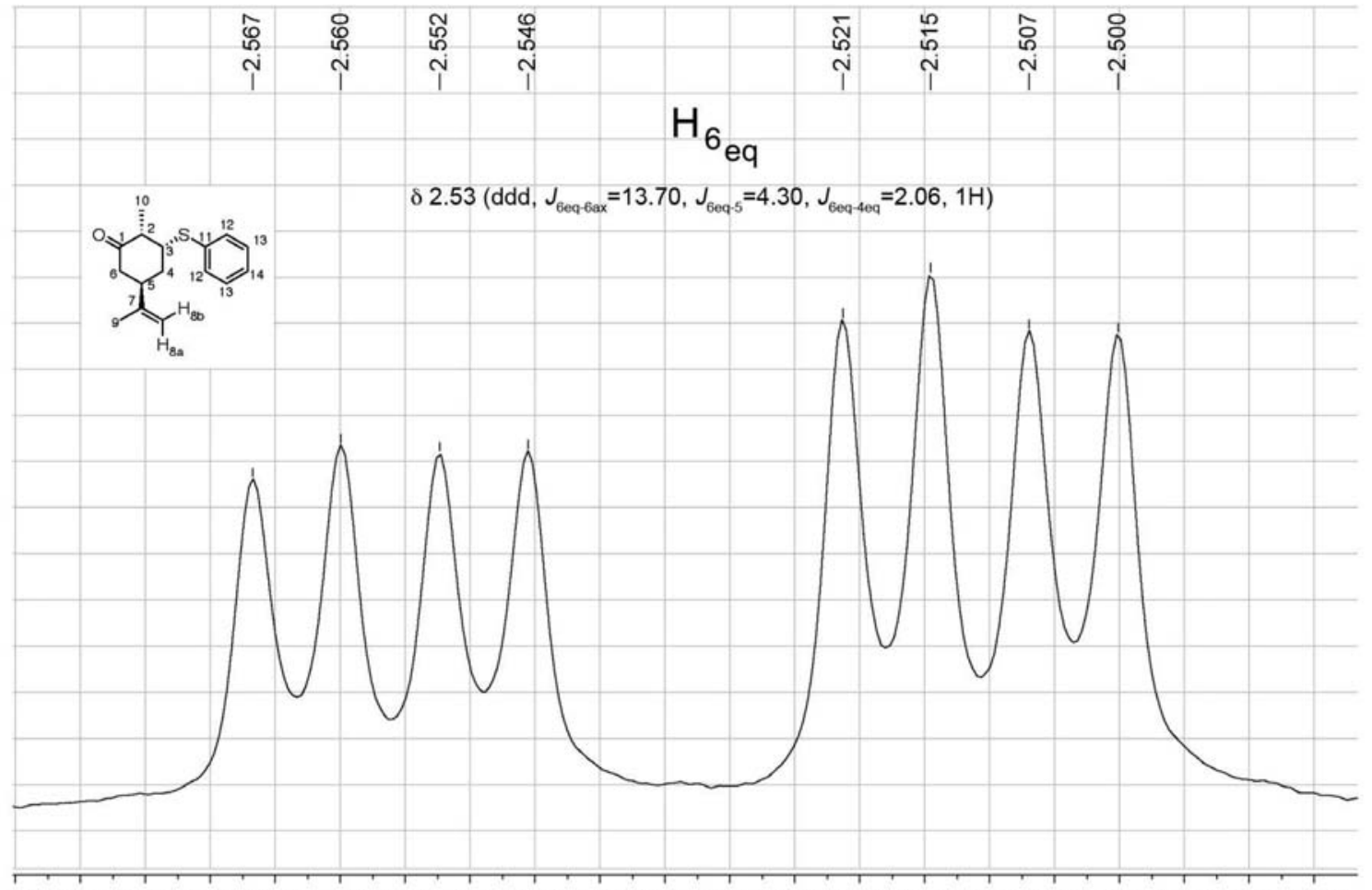

;85 $2.582 .5752 .572 .5652 .562 .5552 .552 .5452 .54 \quad 2.5352 .532 .5252 .522 .5152 .512 .505 \quad 2.5 \quad 2.495 \quad 2.492 .485$

Figure S5. ${ }^{1} \mathrm{H}$ NMR spectrum of compound 14 between $\delta 2.48-2.58\left(400 \mathrm{MHz}, \mathrm{CDCl}_{3}\right)$. 


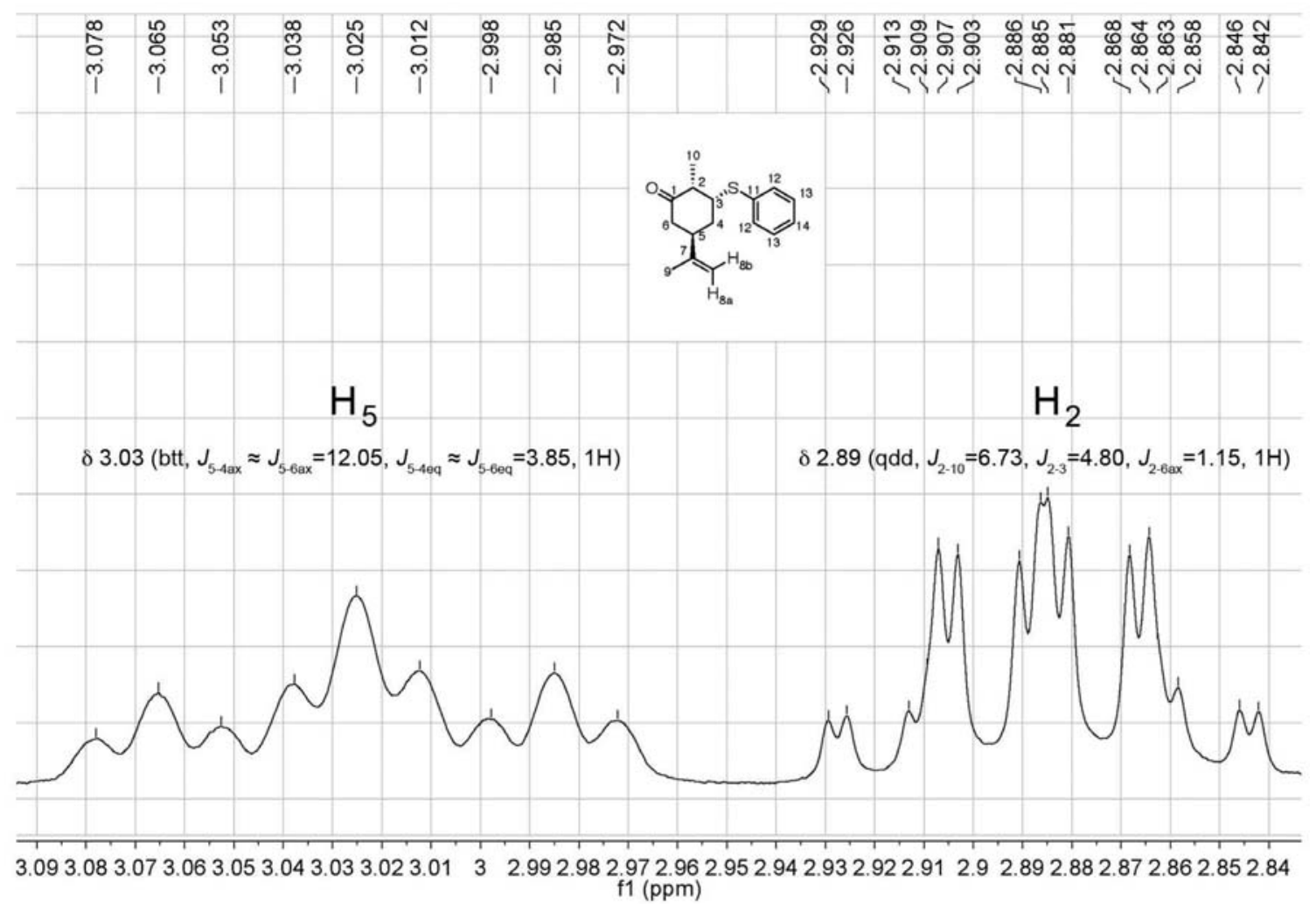

Figure S6. ${ }^{1} \mathrm{H}$ NMR spectrum of compound 14 between $\delta$ 2.84-3.09 (400 MHz, $\left.\mathrm{CDCl}_{3}\right)$.

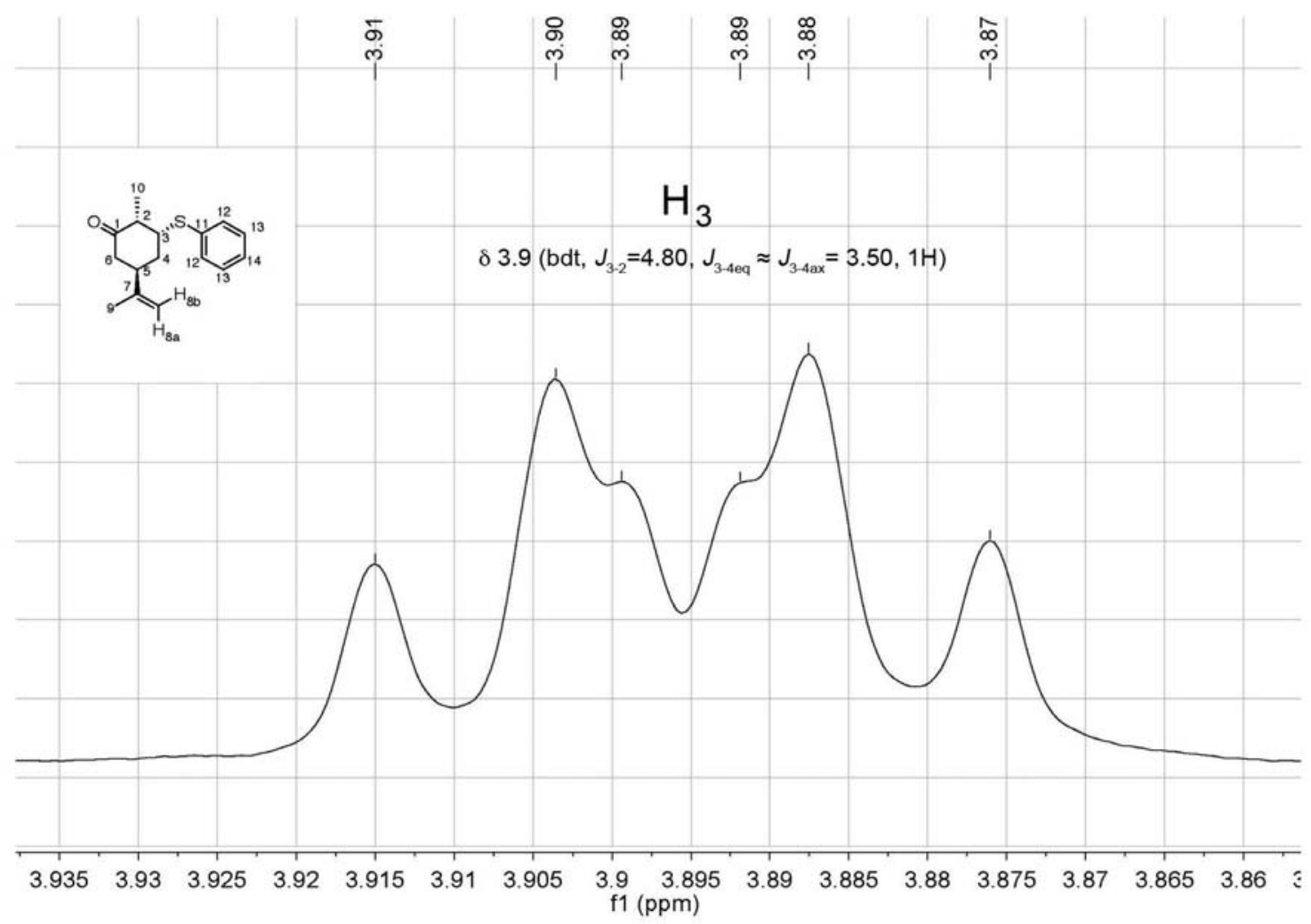

Figure S7. ' $\mathrm{H}$ NMR spectrum of compound 14 between $\delta$ 3.86-3.93 (400 MHz, $\mathrm{CDCl}_{3}$ ). 


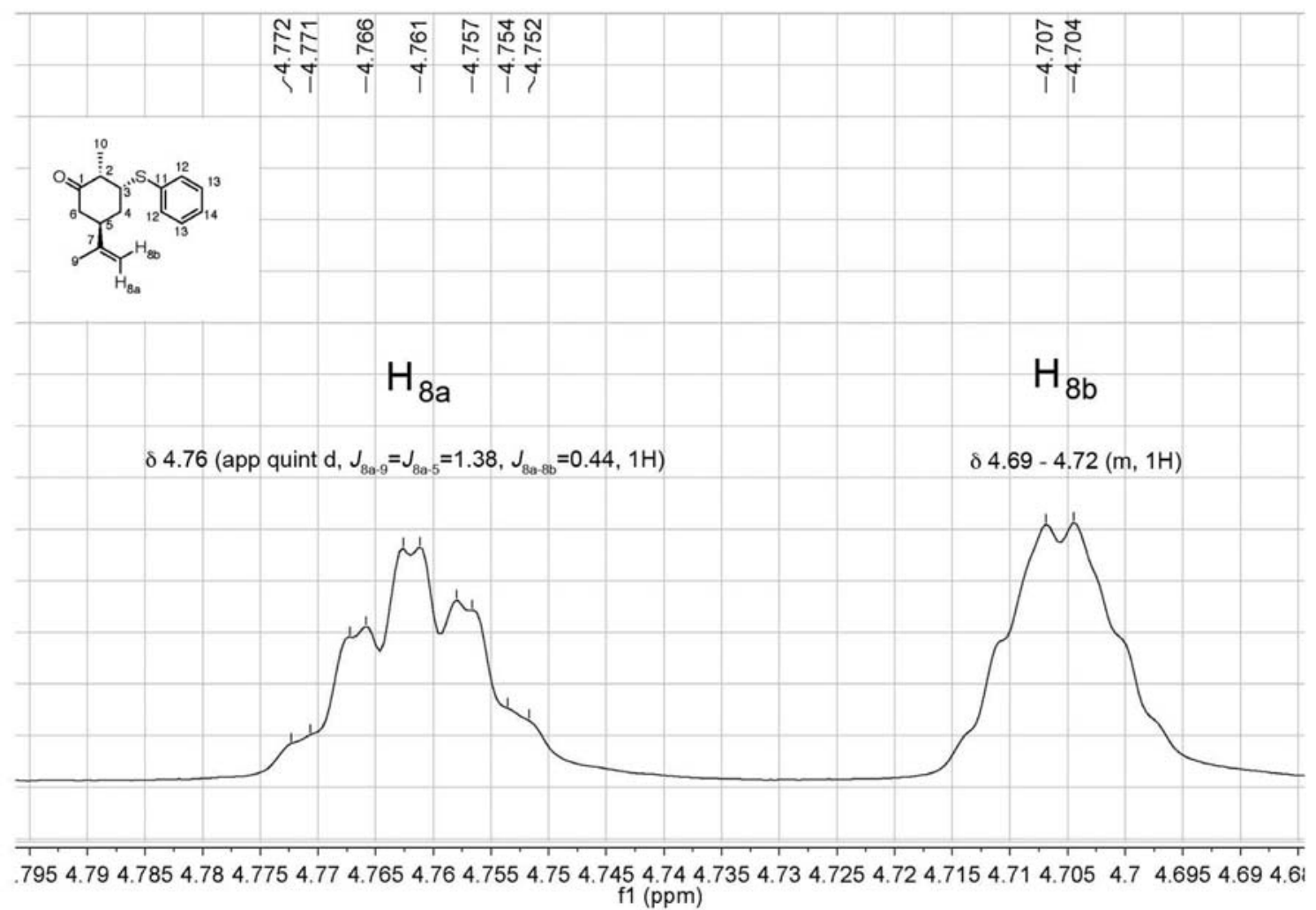

Figure S8. ${ }^{1} \mathrm{H}$ NMR spectrum of compound 14 between $\delta 4.69-4.79\left(400 \mathrm{MHz}, \mathrm{CDCl}_{3}\right)$.

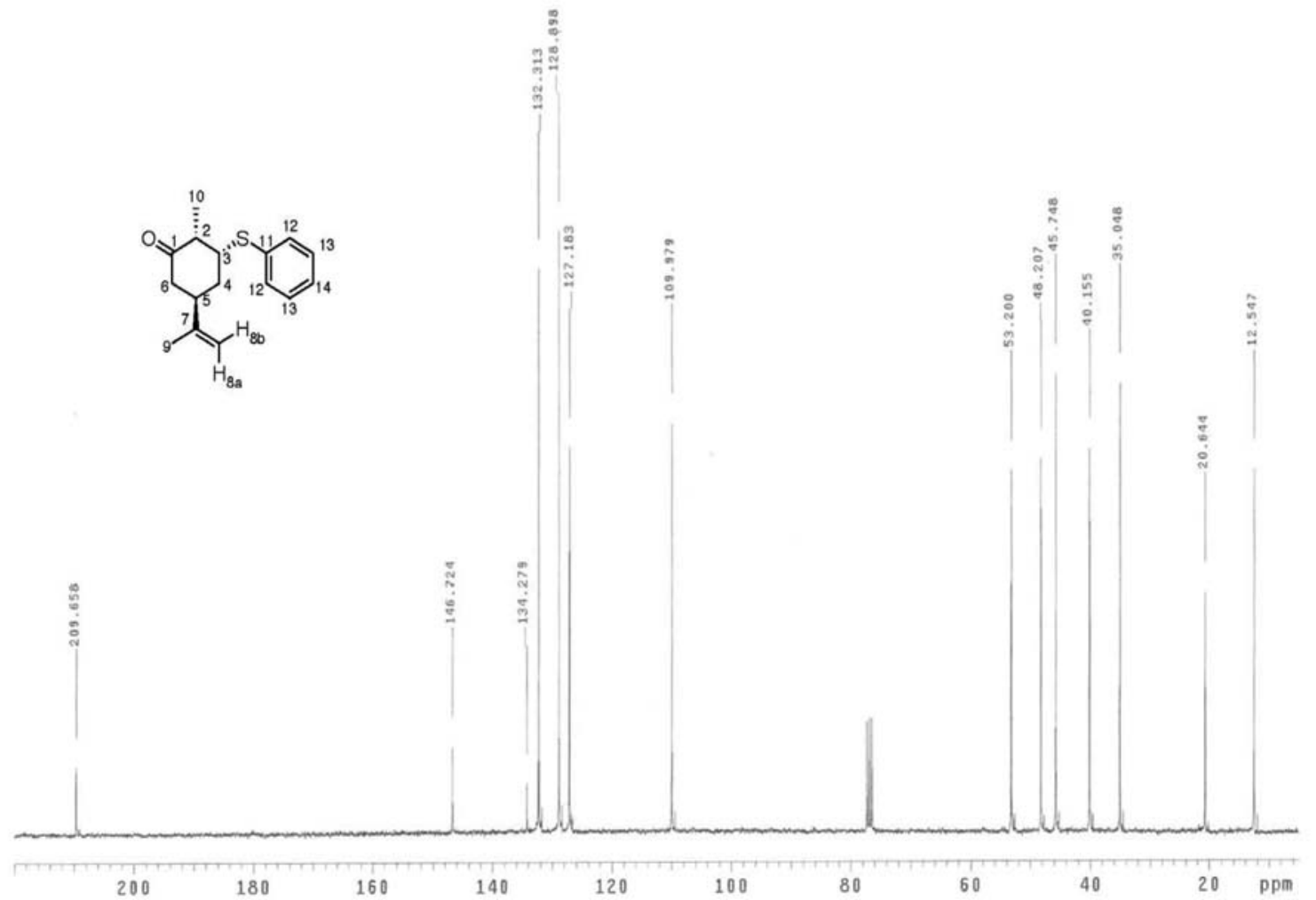

Figure S9. ${ }^{13} \mathrm{C}$ NMR spectrum of compound $14\left(100 \mathrm{MHz}, \mathrm{CDCl}_{3}\right)$. 

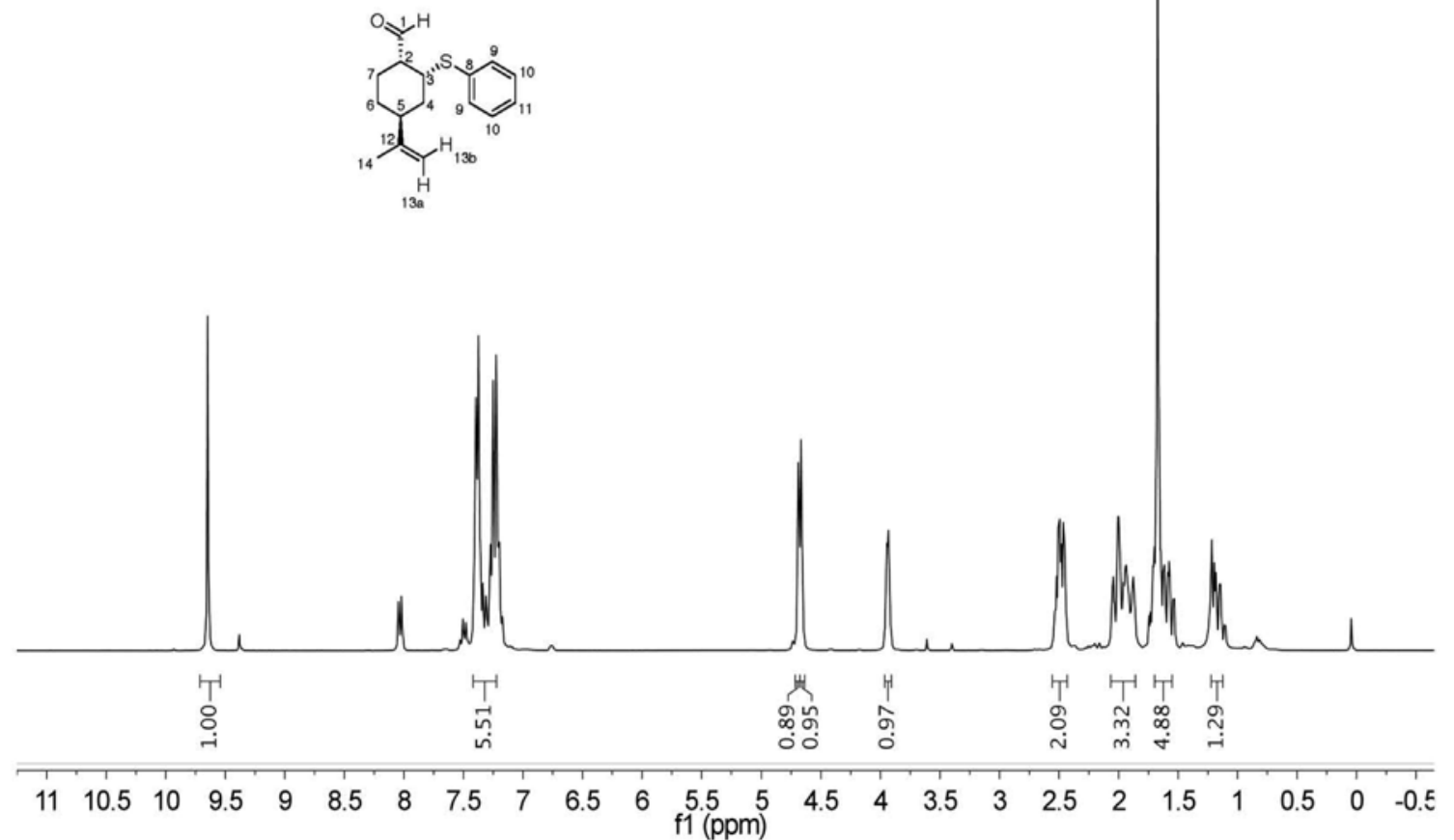

Figure S10. ${ }^{1} \mathrm{H}$ NMR spectrum of compound $16\left(400 \mathrm{MHz}, \mathrm{CDCl}_{3}\right)$.

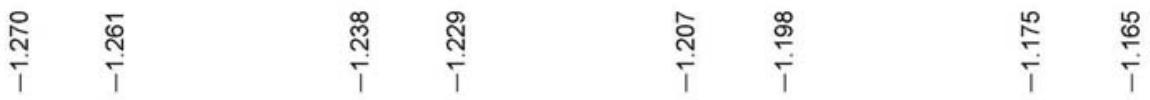

$$
\begin{aligned}
& \mathrm{H}_{6 \mathrm{ax}}
\end{aligned}
$$
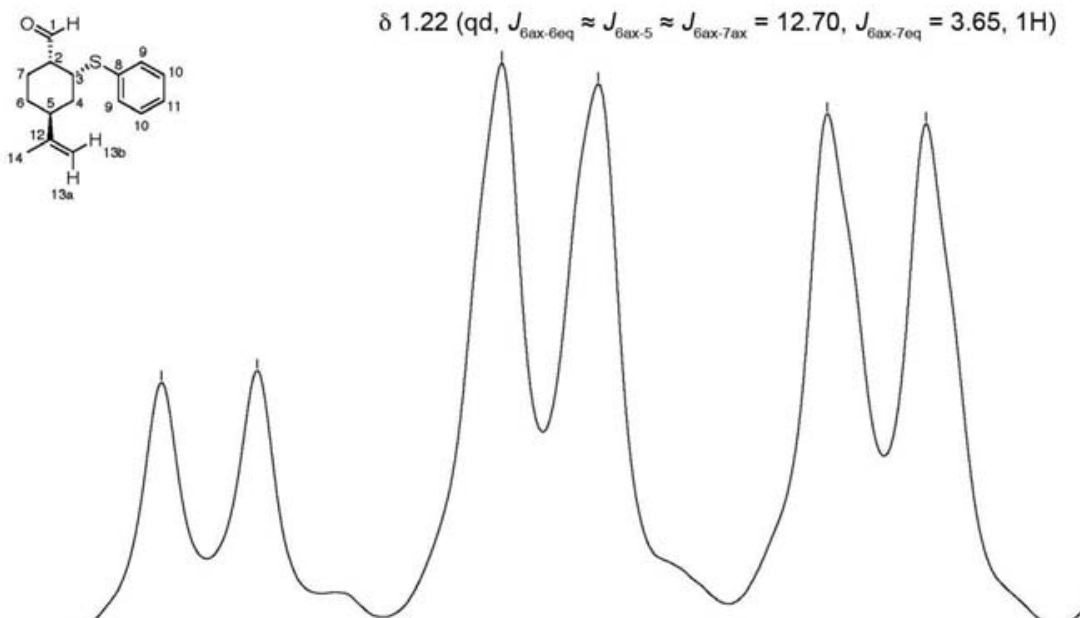

1.281.2751.271.2651.261.2551.251.2451.241.2351.231.2251.221.2151.211.2051.21.1951.191.1851.181.1751.171.1651.161.1551.15 $\mathrm{f} 1(\mathrm{ppm})$

Figure S11. ${ }^{1} \mathrm{H}$ NMR spectrum of compound 16 between $\delta$ 1.15-1.28 (400 MHz, $\left.\mathrm{CDCl}_{3}\right)$. 


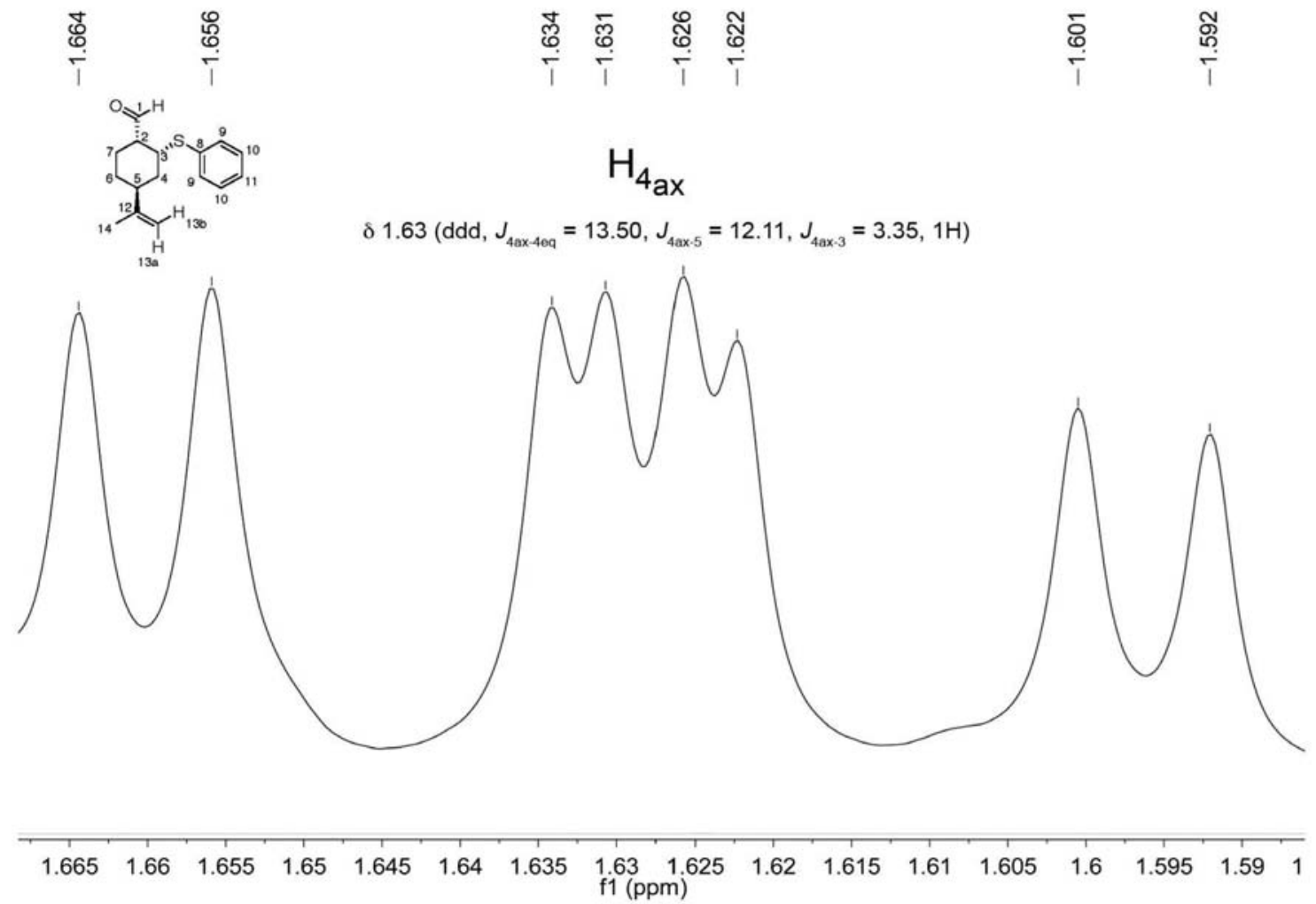

Figure S12. ${ }^{1} \mathrm{H}$ NMR spectrum of compound 16 between $\delta$ 1.59-1.67 (400 MHz, $\left.\mathrm{CDCl}_{3}\right)$.

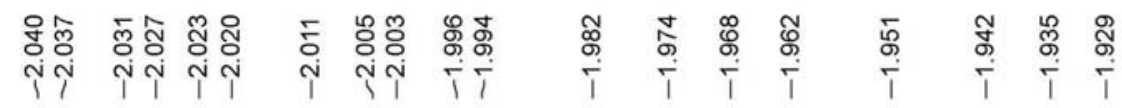
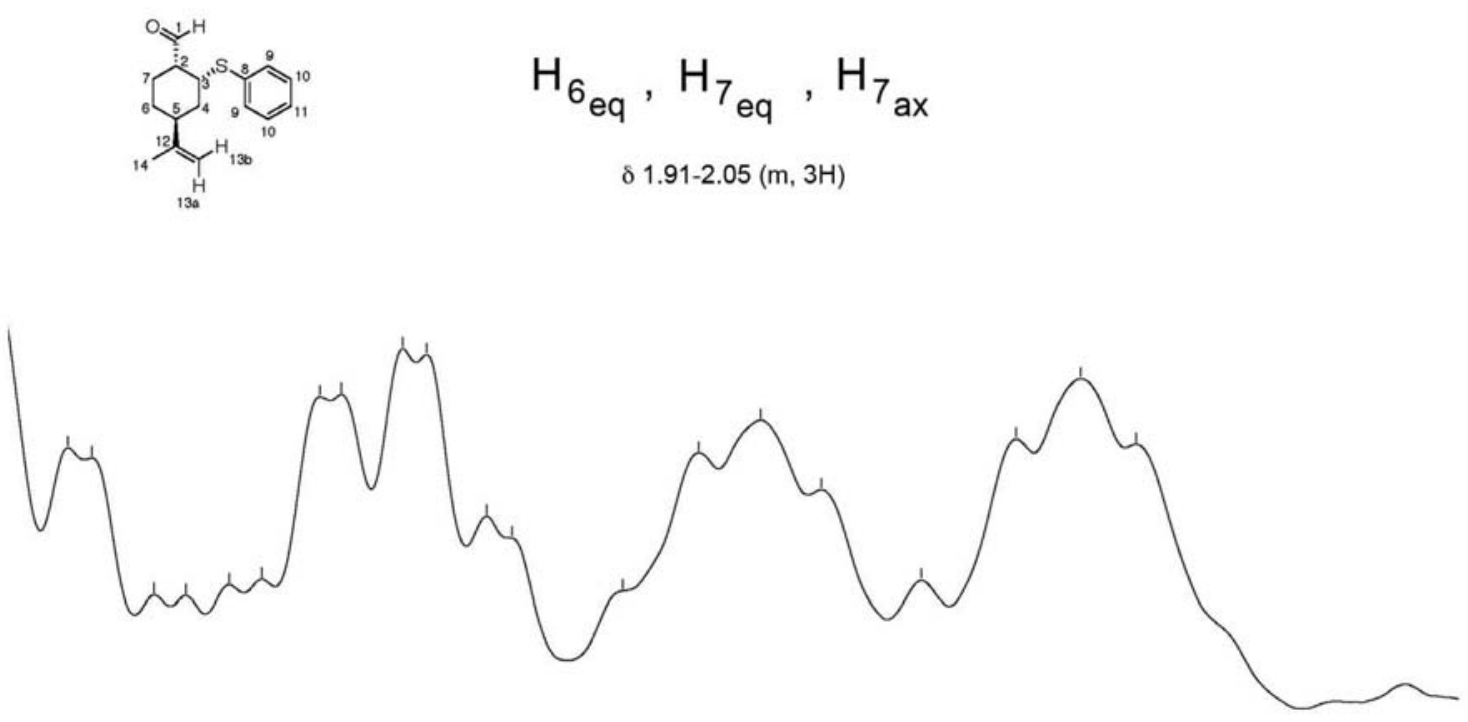

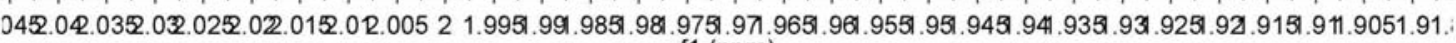
f1 (ppm)

Figure S13. ${ }^{1} \mathrm{H}$ NMR spectrum of compound 16 between $\delta$ 1.91-2.05 (400 MHz, $\left.\mathrm{CDCl}_{3}\right)$. 


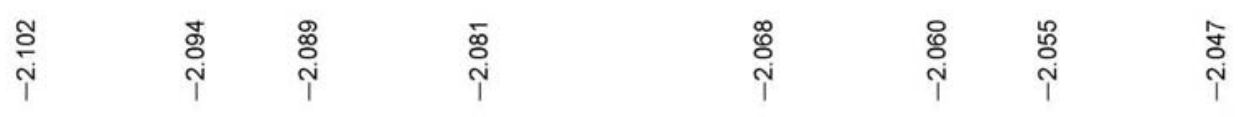

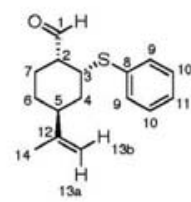

\section{$\mathrm{H}_{4}$ eq}

2.08 (ddd, $\left.J_{4 e q-4 a x}=13.50, J_{4 e q-3}=5.14, J_{4 e q-5}=3.10,1 \mathrm{H}\right)$

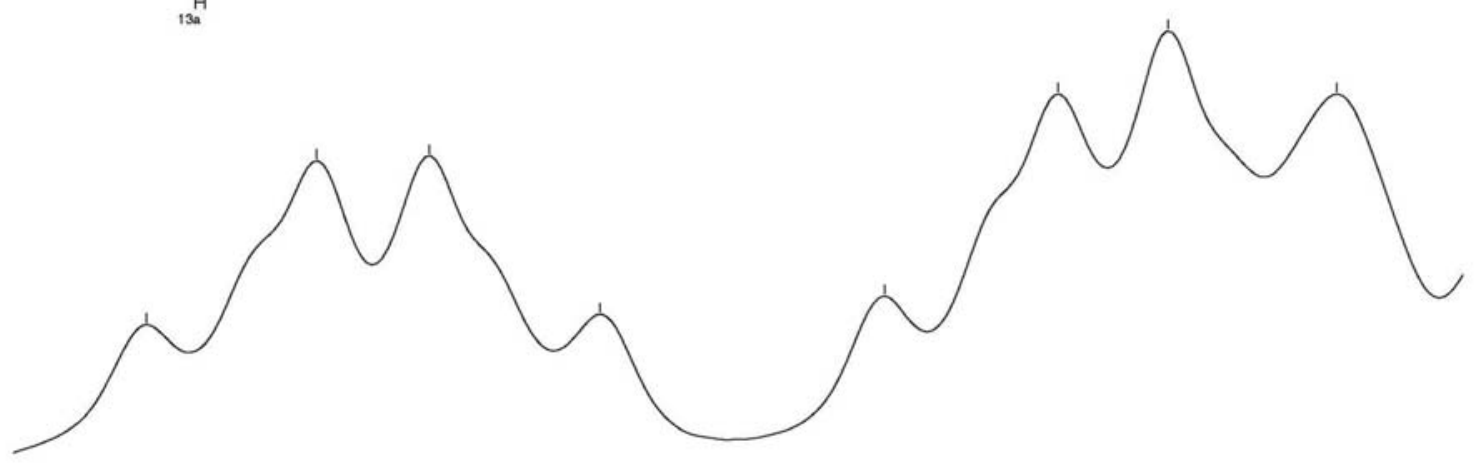

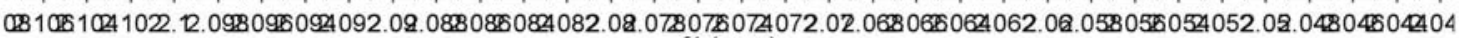
f1 (ppm)

Figure S14. ${ }^{1} \mathrm{H}$ NMR spectrum of compound 16 between $\delta$ 2.04-2.11 (400 $\left.\mathrm{MHz}, \mathrm{CDCl}_{3}\right)$.

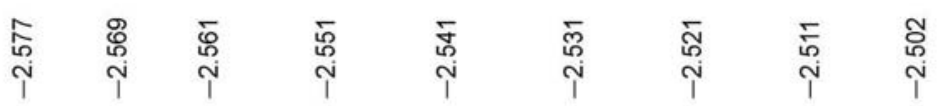

$$
\begin{aligned}
& \mathrm{H}_{2}, \mathrm{H}_{5}
\end{aligned}
$$

$\delta 2.49-2.58(\mathrm{~m}, 2 \mathrm{H})$

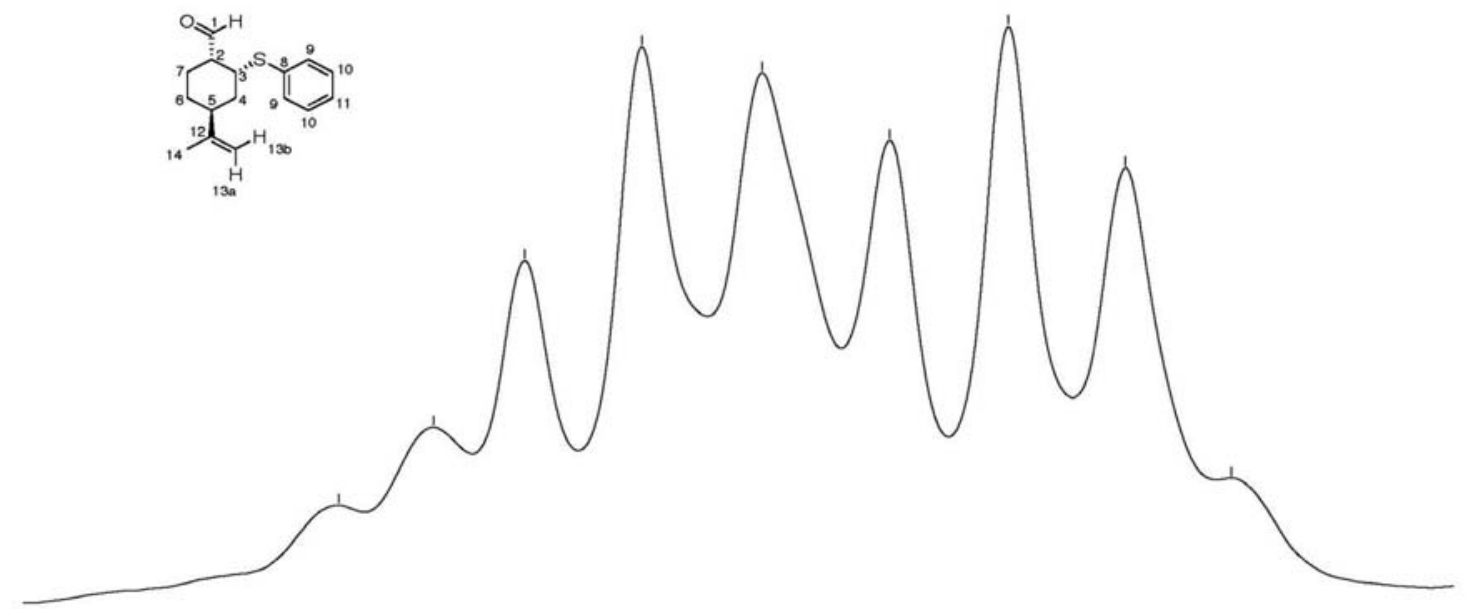

52.62 .5952 .592 .5852 .582 .5752 .572 .5652 .562 .5552 .552 .5452 .542 .5352 .532 .5252 .522 .5152 .512 .5052 .52 .4952 .492 .48 ! $\mathrm{f1}(\mathrm{ppm})$

Figure S15. ${ }^{1} \mathrm{H}$ NMR spectrum of compound 16 between $\delta$ 2.49-2.60 (400 MHz, $\left.\mathrm{CDCl}_{3}\right)$. 
$\mathrm{H}_{3}$

$\delta 3.98$ (app dd, $J_{3-4 e q}=5.97 J_{3-4 a x} \approx J_{3-2}=3.10,1 \mathrm{H}$ )

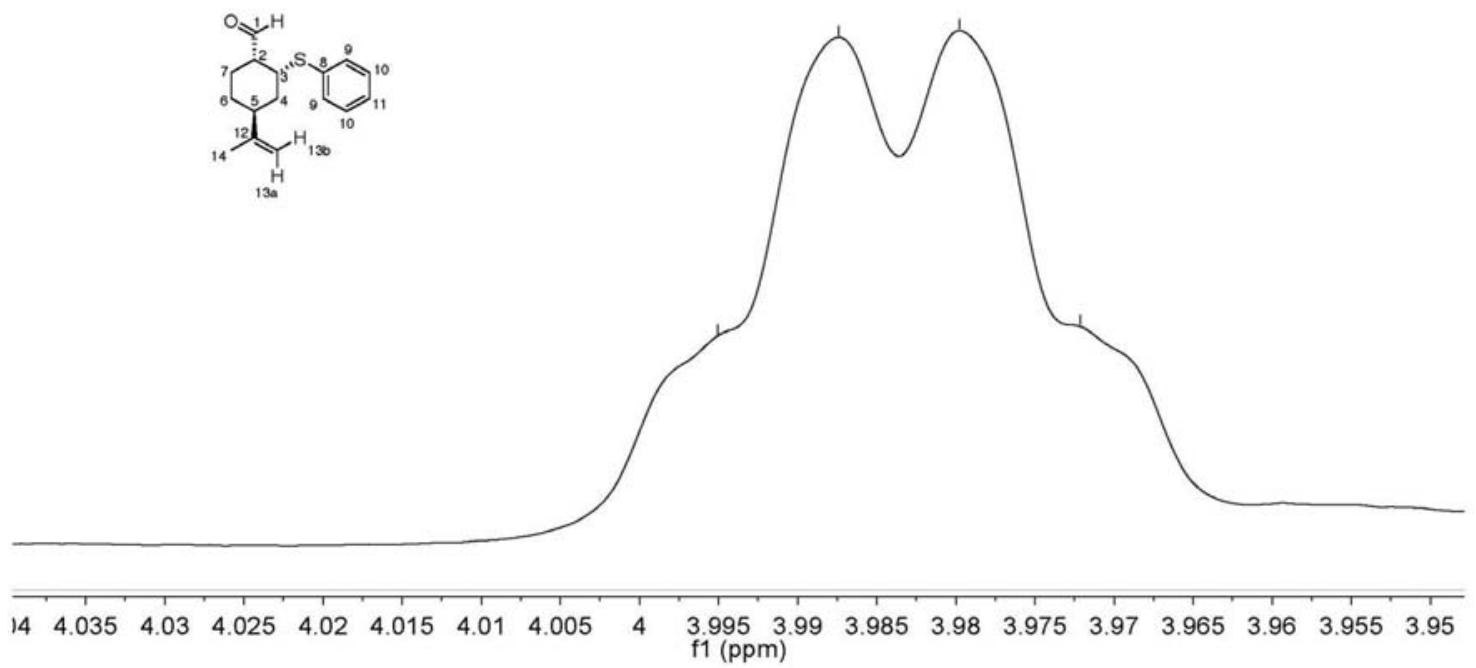

Figure S16. ${ }^{1} \mathrm{H}$ NMR spectrum of compound 16 between $\delta$ 3.95-4.03 (400 MHz, $\mathrm{CDCl}_{3}$ ).
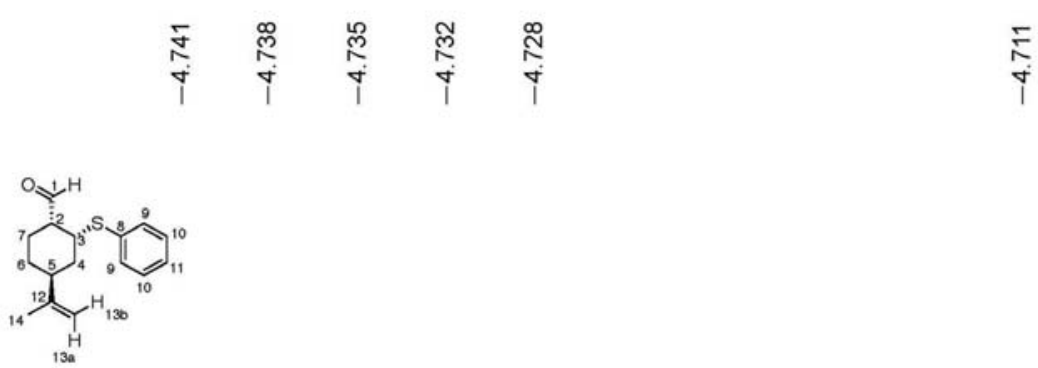

$\mathrm{H}_{13 \mathrm{a}} \quad \mathrm{H}_{13 \mathrm{~b}}$

$\delta 4.73$ (app quint, $J_{13 a-14} \approx J_{13 a-5}=1.30,1 \mathrm{H}$ ) $\quad 4.71$ (app s, $1 \mathrm{H}$ )

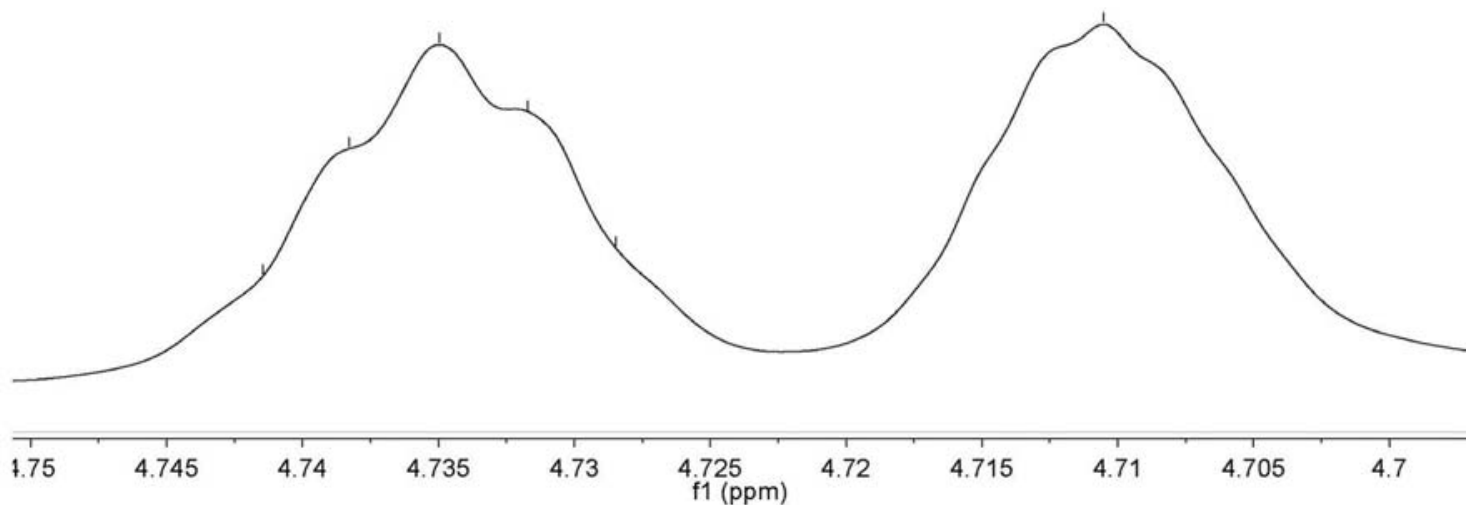

Figure S17. ${ }^{1} \mathrm{H}$ NMR spectrum of compound 16 between $\delta$ 4.70-4.75 (400 MHz, $\mathrm{CDCl}_{3}$ ). 


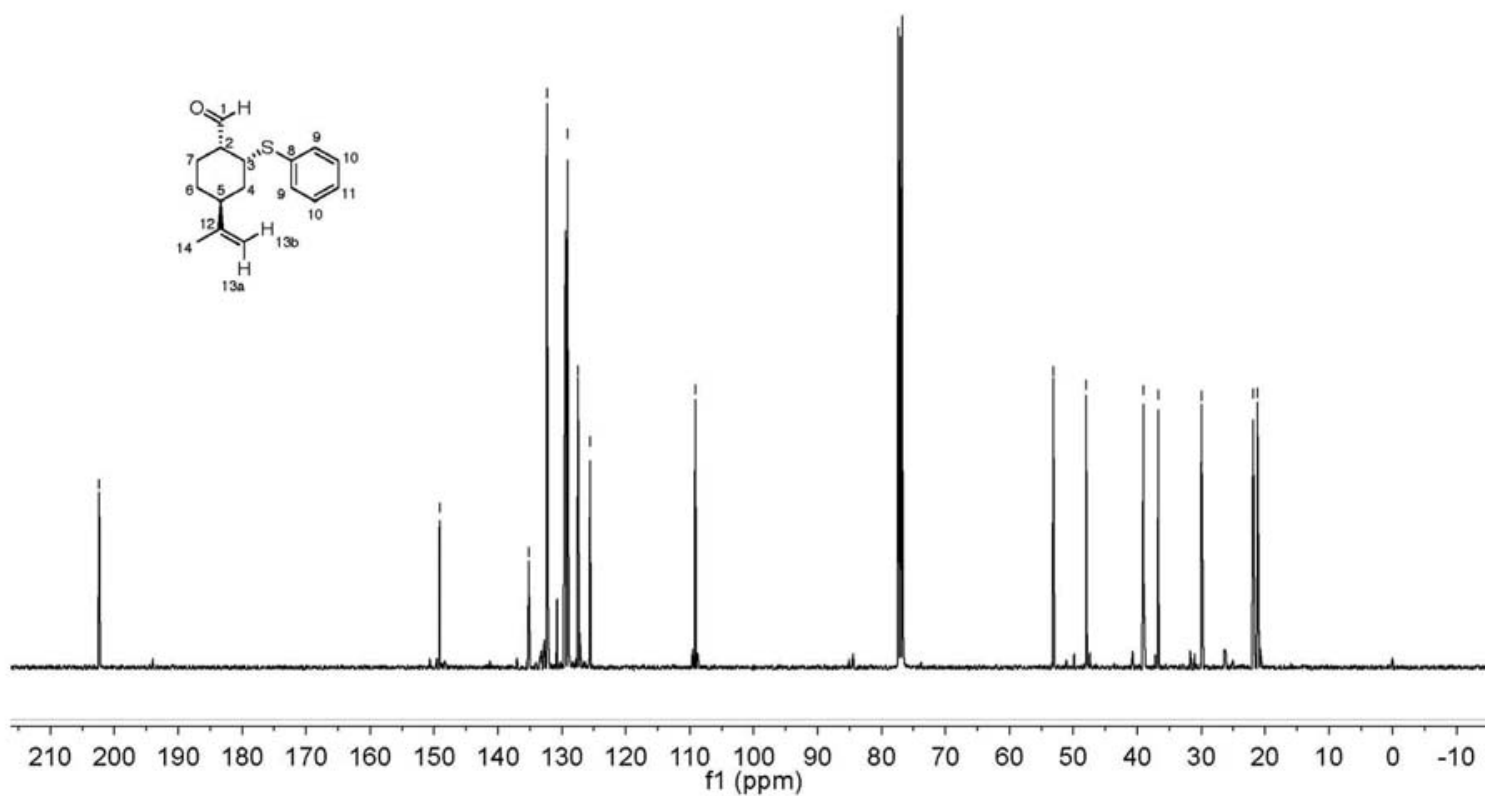

Figure S18. ${ }^{13} \mathrm{C}$ NMR spectrum of compound $16\left(100 \mathrm{MHz}, \mathrm{CDCl}_{3}\right)$.

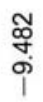
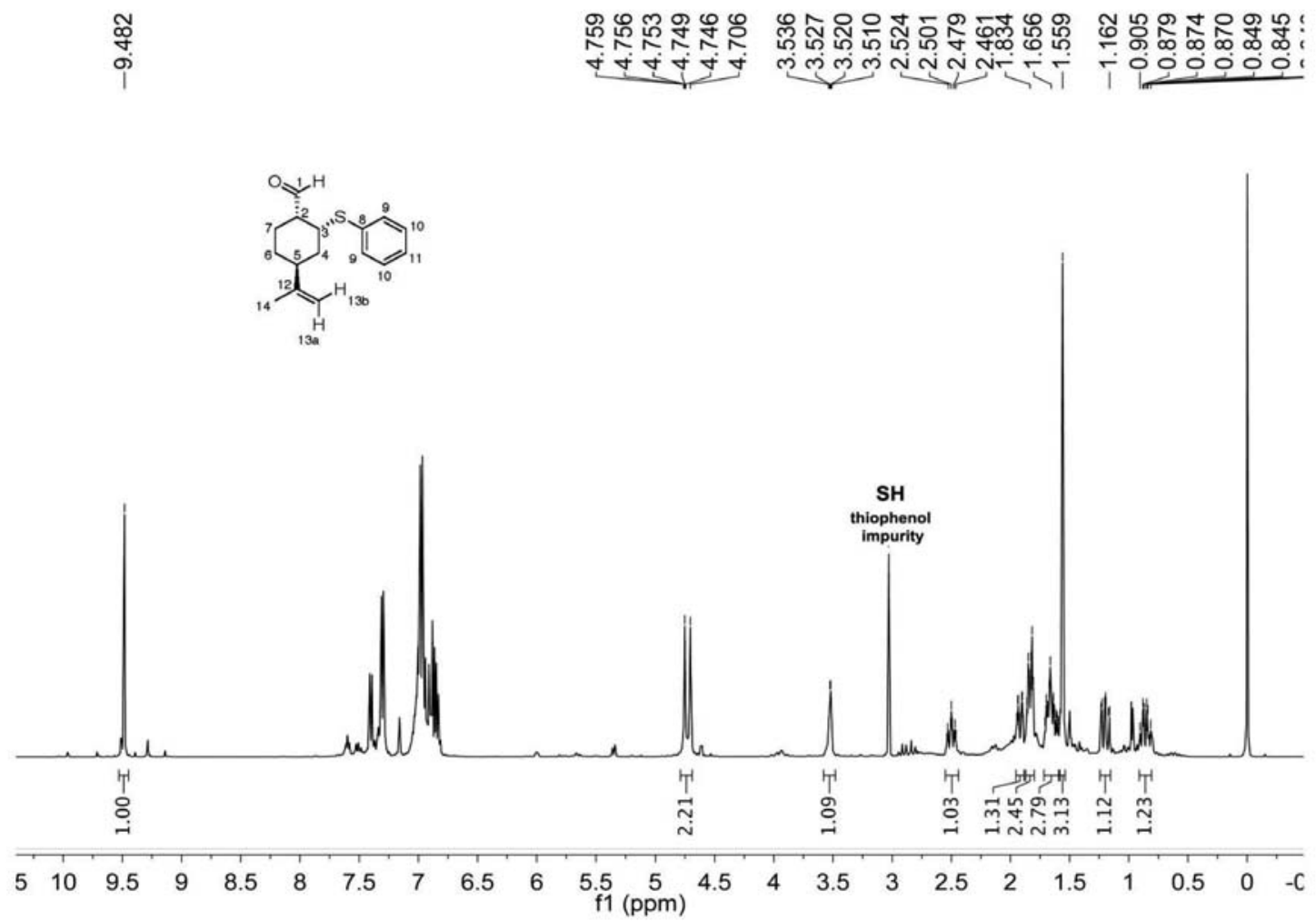

Figure S19. ${ }^{1} \mathrm{H}$ NMR spectrum of compound $\mathbf{1 6}\left(400 \mathrm{MHz}, \mathrm{C}_{6} \mathrm{D}_{6}\right)$. 


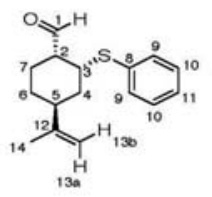

$$
\mathrm{H}_{6 \text { ax }}
$$

$\delta 0.86$ (qd, $\left.J_{6 a x-6 e q} \approx J_{6 a x-5} \approx J_{6 a x-7 a x}=12.20, J_{6 a x-7 \text { eq }}=3.60,1 \mathrm{H}\right)$

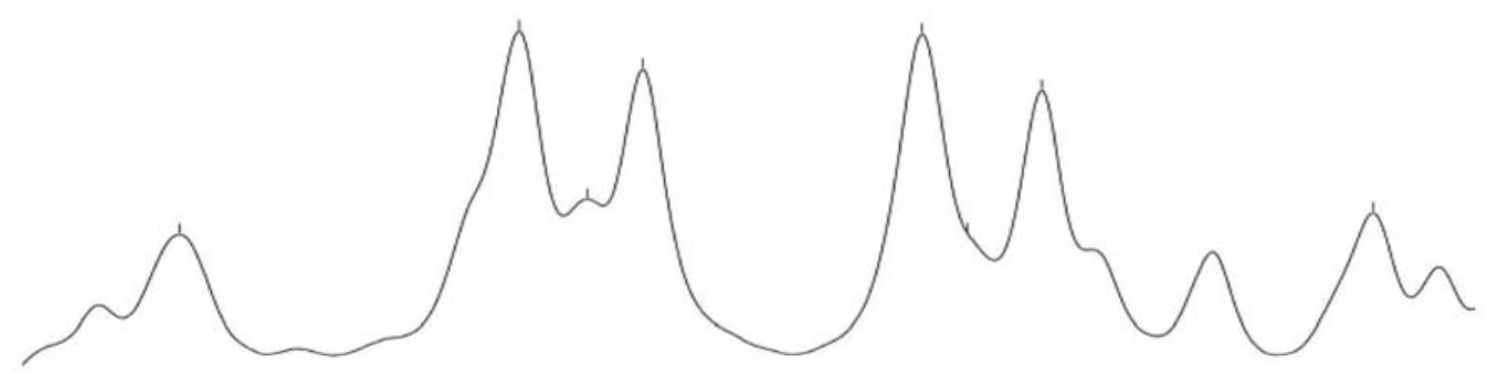

$\begin{array}{llllllllllllllllllllllllllllllllllll}0.915 & 0.91 & 0.905 & 0.9 & 0.895 & 0.89 & 0.885 & 0.88 & 0.875 & 0.87 & 0.865 & 0.86 & 0.855 & 0.85 & 0.845 & 0.84 & 0.835 & 0.83 & 0.825 & 0.82 & 0.815 & 0.81 & C\end{array}$

Figure S20. ${ }^{1} \mathrm{H}$ NMR spectrum of compound 16 between $\delta 0.80-0.91\left(400 \mathrm{MHz}, \mathrm{C}_{6} \mathrm{D}_{6}\right)$.

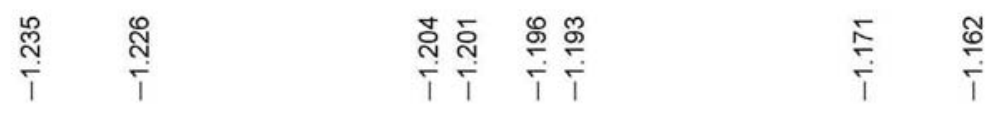

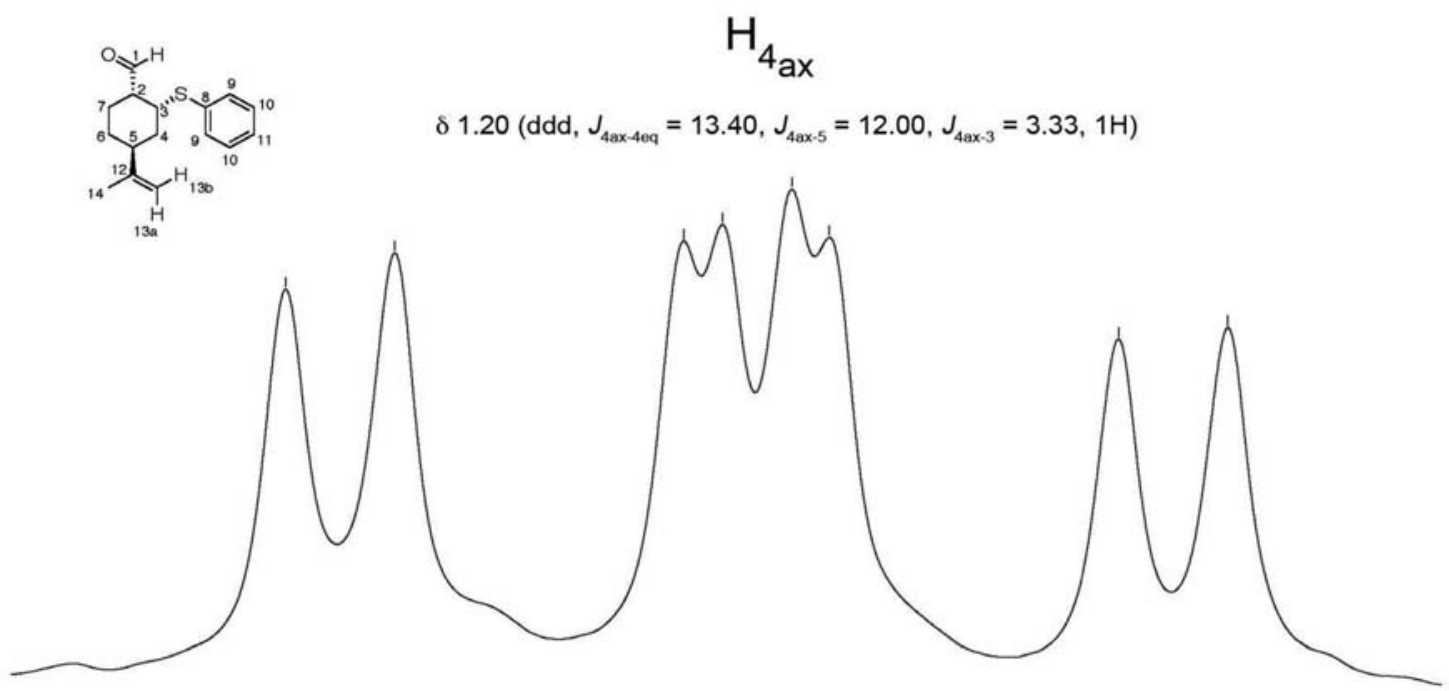

2551.251 .2451 .241 .2351 .231 .2251 .221 .2151 .211 .205121 .1951 .191 .1851 .181 .1751 .171 .1651 .161 .1551 .151$. f1 (ppm)

Figure S21. ${ }^{1} \mathrm{H}$ NMR spectrum of compound 16 between $\delta 1.15-1.25\left(400 \mathrm{MHz}, \mathrm{C}_{6} \mathrm{D}_{6}\right)$. 


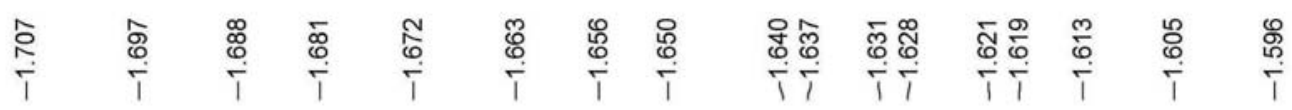

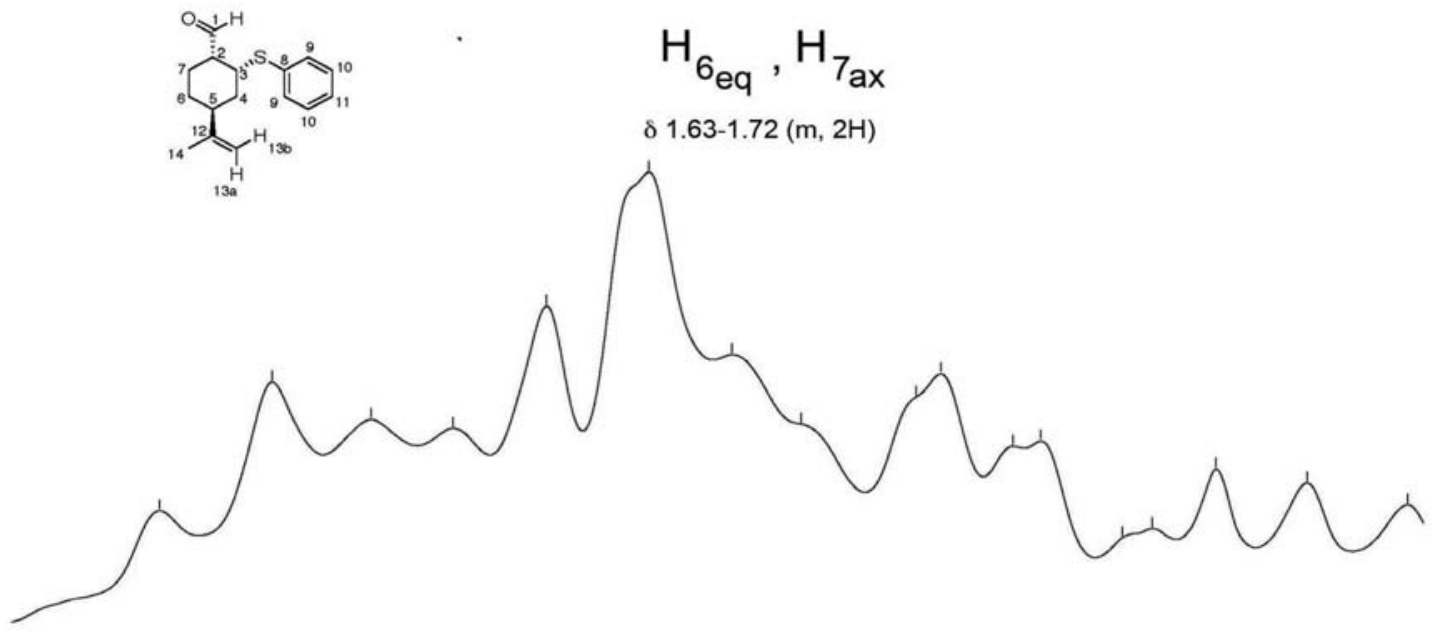

721.7151.711.705 1.71.6951.691.6851.681.6751.671.6651.661.6551.651.6451.641.6351.631.6251.621.6151.611.6051.61.5 f1 $(\mathrm{ppm})$

Figure S22. ${ }^{1} \mathrm{H}$ NMR spectrum of compound 16 between $\delta 1.59-1.72\left(400 \mathrm{MHz}, \mathrm{C}_{6} \mathrm{D}_{6}\right)$.

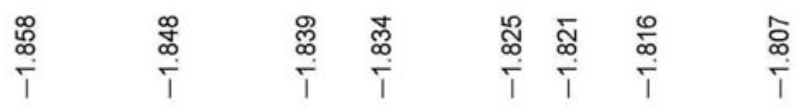

$$
\mathrm{H}_{2}, \mathrm{H}_{7 \text { eq }}
$$

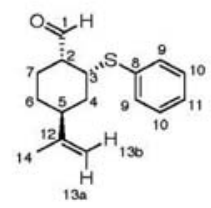

$\delta 1.77-1.88(\mathrm{~m}, 2 \mathrm{H})$

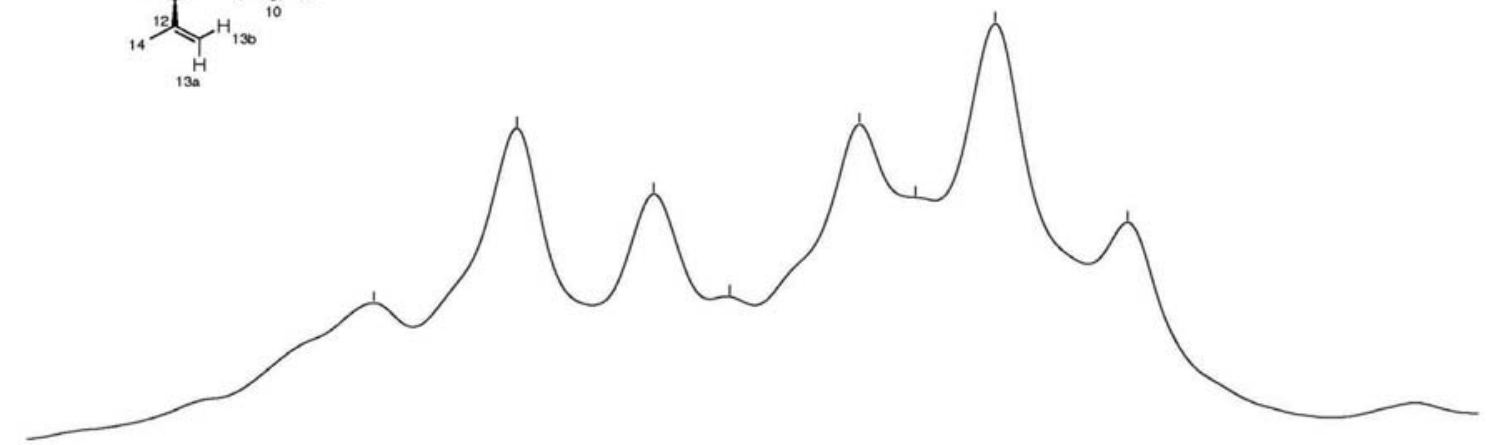

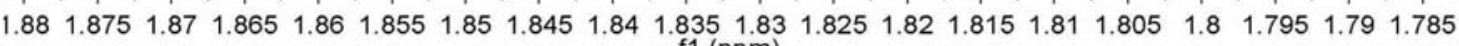
f1 (ppm)

Figure S23. ${ }^{1} \mathrm{H}$ NMR spectrum of compound 16 between $\delta$ 1.77-1.88 (400 MHz, $\left.\mathrm{C}_{6} \mathrm{D}_{6}\right)$. 


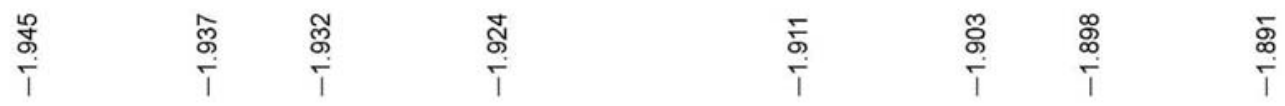

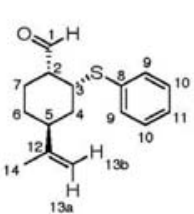

$\mathrm{H}_{4}$ eq

$\delta 1.92\left(\mathrm{ddd}, \mathrm{J}_{4 \mathrm{eq}-\mathrm{Aax}}=13.40, \mathrm{~J}_{4 \mathrm{eq}-3}=5.10, \mathrm{~J}_{4 \mathrm{eq}-5}=3.10,1 \mathrm{H}\right)$

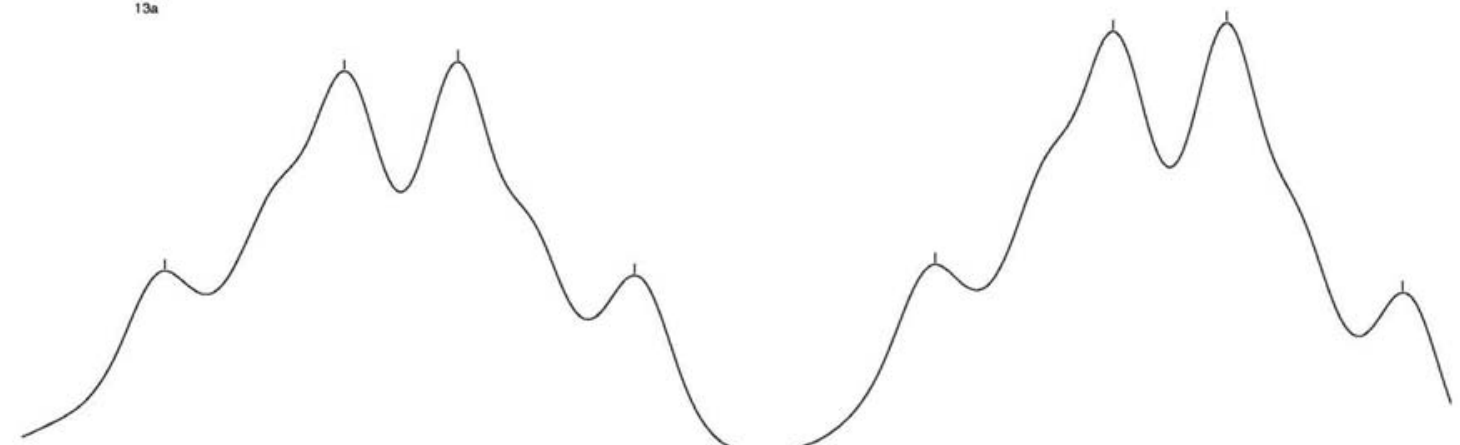

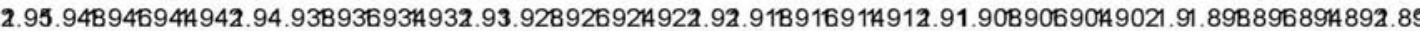
$\mathrm{f} 1(\mathrm{ppm})$

Figure S24. ${ }^{1} \mathrm{H}$ NMR spectrum of compound 16 between $\delta$ 1.88-1.95 (400 MHz, $\left.\mathrm{C}_{6} \mathrm{D}_{6}\right)$.

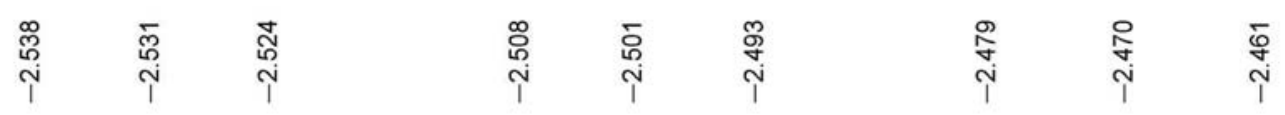

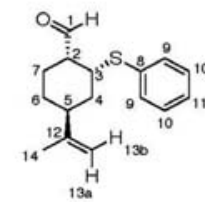

$\mathrm{H}_{5}$

$\delta 2.50\left(\mathrm{tt}, J_{5-409} \approx J_{5-60 \mathrm{q}}=3.10, J_{5-4 a x} \approx J_{5-6 a x}=12.00,1 \mathrm{H}\right)$

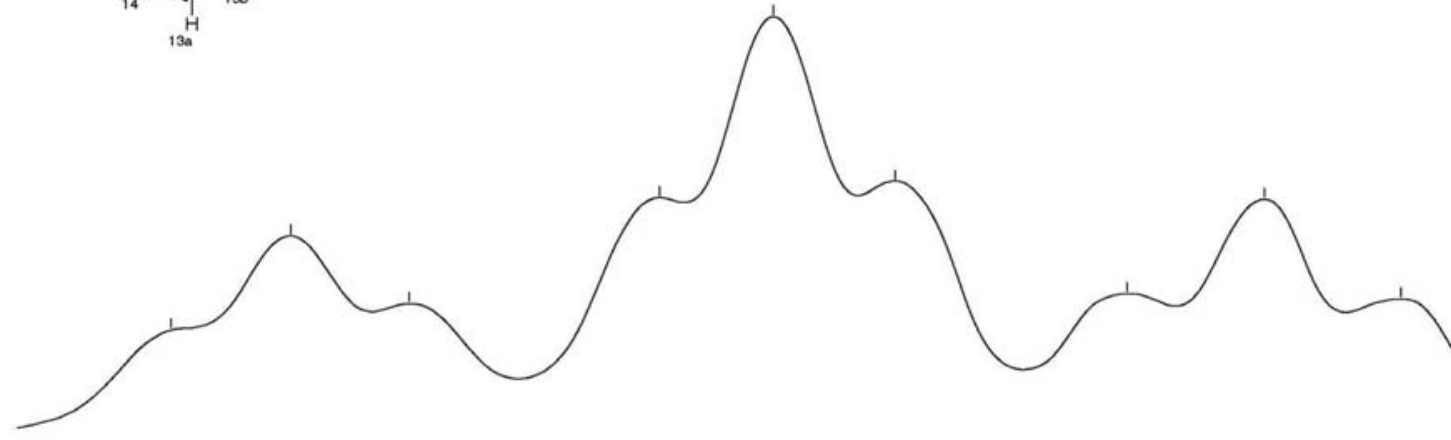

$\begin{array}{llllllllllllllllll}2.545 & 2.54 & 2.535 & 2.53 & 2.525 & 2.52 & 2.515 & 2.51 & 2.505 & 2.5 & 2.495 & 2.49 & 2.485 & 2.48 & 2.475 & 2.47 & 2.465 & 2.46\end{array}$

Figure S25. ${ }^{1} \mathrm{H}$ NMR spectrum of compound $\mathbf{1 6}$ between $\delta$ 2.45-2.54 (400 MHz, $\left.\mathrm{C}_{6} \mathrm{D}_{6}\right)$. 


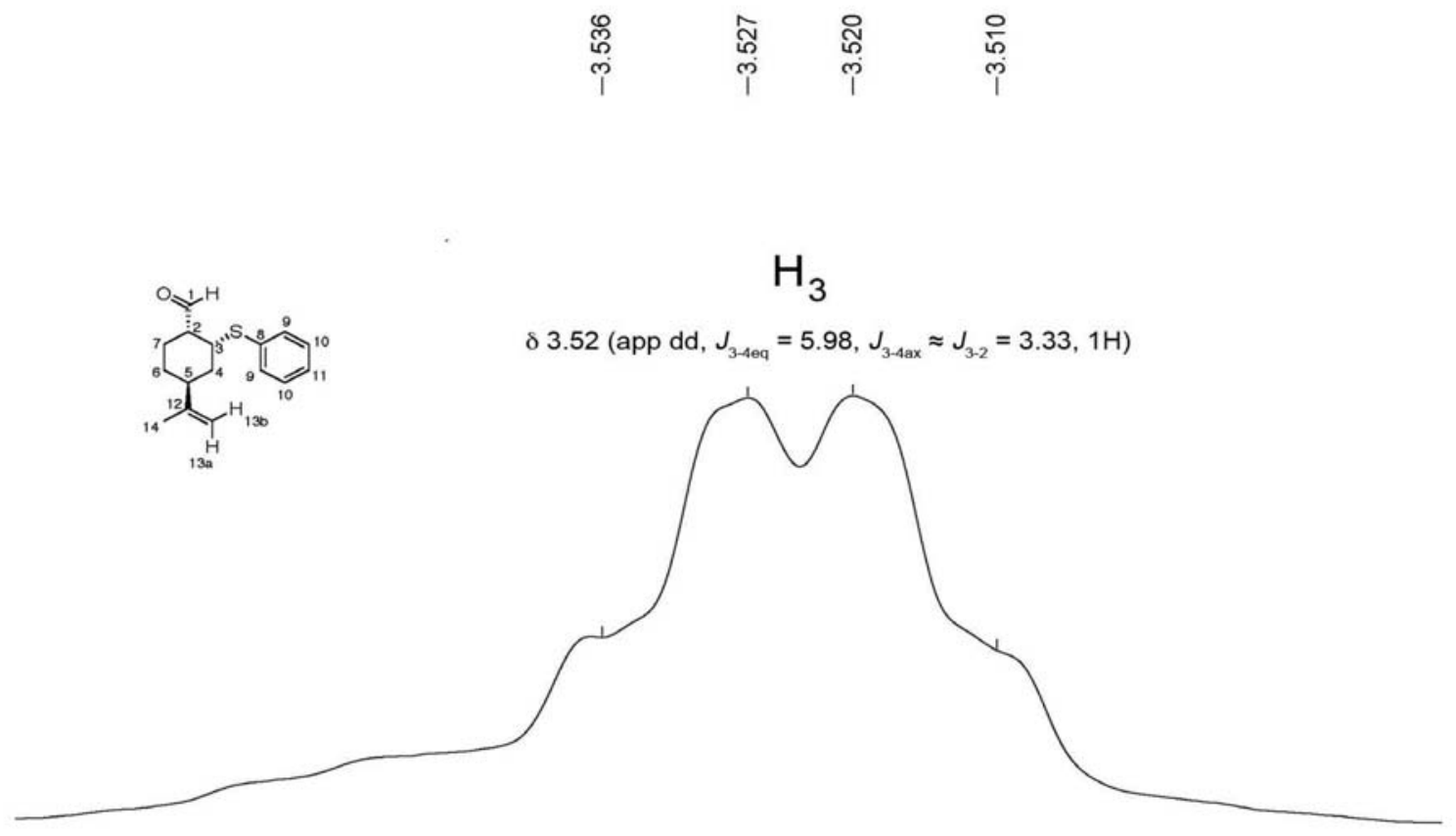

$\begin{array}{llllllllllllllllllll}575 & 3.57 & 3.565 & 3.56 & 3.555 & 3.55 & 3.545 & 3.54 & 3.535 & 3.53 & 3.525 & 3.52 & 3.515 & 3.51 & 3.505 & 3.5 & 3.495 & 3.49 & 3.485 & 3\end{array}$ $\mathrm{f} 1(\mathrm{ppm})$

Figure S26. ${ }^{1} \mathrm{H}$ NMR spectrum of compound 16 between $\delta 3.49-3.57\left(400 \mathrm{MHz}, \mathrm{C}_{6} \mathrm{D}_{6}\right)$.

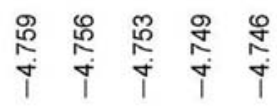

$\mathrm{H}_{13 a}$

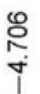

$\mathrm{H}_{13 \mathrm{~b}}$

$\delta 4.71($ app s, $1 \mathrm{H})$

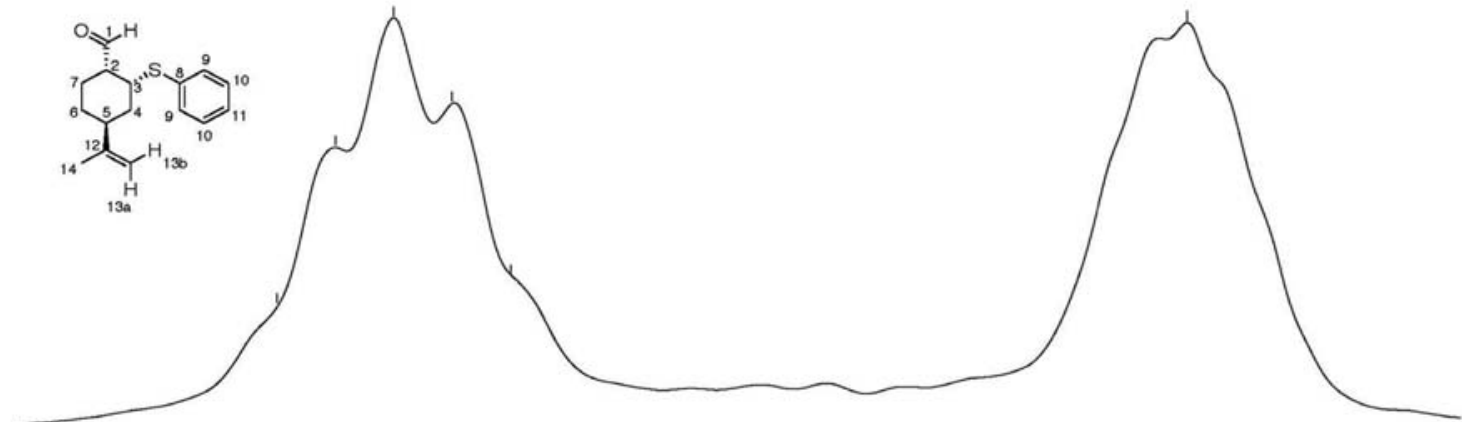

$\begin{array}{lllllllllllllllllll}75 & 4.77 & 4.765 & 4.76 & 4.755 & 4.75 & 4.745 & 4.74 & \begin{array}{c}4.735 \\ \mathrm{f} 1(\mathrm{ppm})\end{array} & 4.7325 & 4.72 & 4.715 & 4.71 & 4.705 & 4.7 & 4.695 & 4.6\end{array}$

Figure S27. ${ }^{1} \mathrm{H}$ NMR spectrum of compound 16 between $\delta 4.69-4.78\left(400 \mathrm{MHz}, \mathrm{C}_{6} \mathrm{D}_{6}\right)$. 


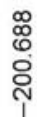

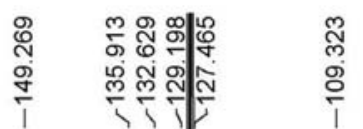

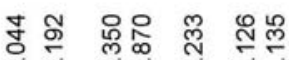

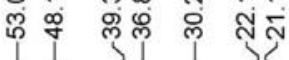
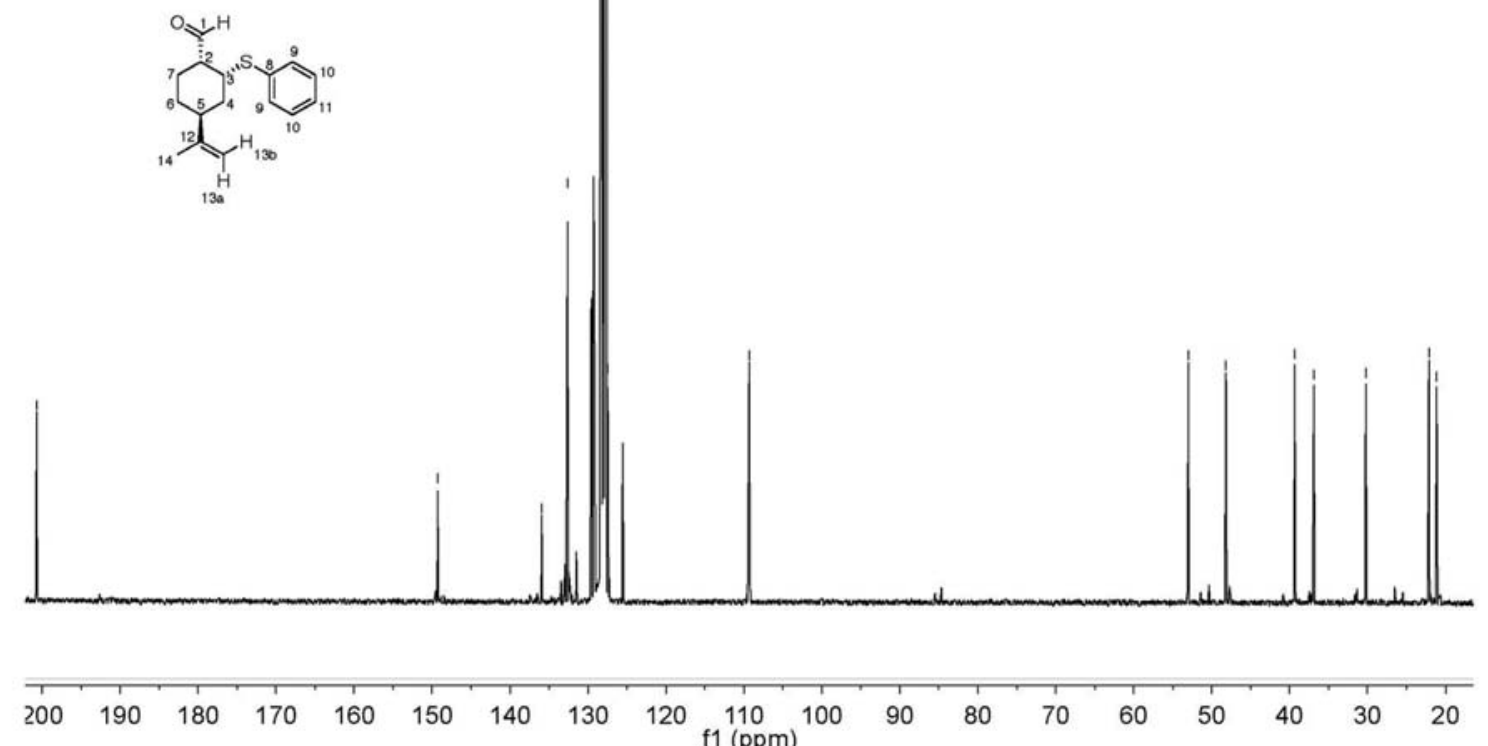

Figure S28. ${ }^{13} \mathrm{C}$ NMR spectrum of compound $16\left(100 \mathrm{MHz}, \mathrm{C}_{6} \mathrm{D}_{6}\right)$. 